\title{
Modulation of Progesterone Receptor Isoform Expression in Pregnant Human Myometrium
}

\author{
Marina Ilicic, ${ }^{1,2,3}$ Tamas Zakar, ${ }^{1,2,3,4}$ and Jonathan W. Paul ${ }^{1,2,3}$ \\ ${ }^{1}$ School of Medicine and Public Health, Faculty of Health and Medicine, University of Newcastle, Callaghan, NSW 2308, Australia \\ ${ }^{2}$ Priority Research Centre for Reproductive Science, University of Newcastle, Callaghan, NSW 2308, Australia \\ ${ }^{3}$ Hunter Medical Research Institute, 1 Kookaburra Circuit, New Lambton Heights, NSW 2305, Australia \\ ${ }^{4}$ John Hunter Hospital, New Lambton Heights, NSW 2305, Australia
}

Correspondence should be addressed to Jonathan W. Paul; jonathan.paul@newcastle.edu.au

Received 26 February 2017; Accepted 6 April 2017; Published 2 May 2017

Academic Editor: Nadia Alfaidy

Copyright (C) 2017 Marina Ilicic et al. This is an open access article distributed under the Creative Commons Attribution License, which permits unrestricted use, distribution, and reproduction in any medium, provided the original work is properly cited.

Background. Regulation of myometrial progesterone receptor (PR) expression is an unresolved issue central to understanding the mechanism of functional progesterone withdrawal and initiation of labor in women. Objectives. To determine whether pregnant human myometrium undergoes culture-induced changes in $P R$ isoform expression ex situ and, further, to determine if conditions approaching the in vivo environment stabilise $P R$ isoform expression in culture. Methods. Term nonlaboring human myometrial tissues were cultured under specific conditions: serum supplementation, steroids, stretch, cAMP, PMA, PGF $2 \alpha, \mathrm{NF} \kappa \mathrm{B}$ inhibitors, or TSA. Following $48 \mathrm{~h}$ culture, $P R-T, P R-A$, and $P R-B$ mRNA levels were determined using qRT-PCR. $P R-A / P R-B$ ratios were calculated. Results. $P R-T$ and $P R-A$ expression and the $P R-A / P R-B$ ratio significantly increased in culture. Steroids prevented the culture-induced increase in $P R-T$ and $P R-A$ expression. Stretch blocked the effects of steroids on $P R-T$ and $P R-A$ expression. PMA further increased the $P R-A / P R-B$ ratio, while TSA blocked culture-induced increases of $P R-A$ expression and the $P R-A / P R-B$ ratio. Conclusion. Human myometrial tissue in culture undergoes changes in $P R$ gene expression consistent with transition toward a laboring phenotype. TSA maintained the nonlaboring PR isoform expression pattern. This suggests that preserving histone and/or nonhistone protein acetylation is critical for maintaining the progesterone dependent quiescent phenotype of human myometrium in culture.

\section{Introduction}

Preterm birth is a major societal and economic problem that affects approximately $9.6 \%$ of pregnancies worldwide and accounts for $80-90 \%$ of neonatal morbidity and death [1-4]. The prevention of preterm birth continues to be an important health priority. There is a substantial body of evidence highlighting the importance of progesterone in maintaining the pregnant state by promoting myometrial quiescence and relaxation [5-7]. The withdrawal of progesterone action signals the end of pregnancy and in most mammalian species happens by a rapid fall in circulating levels of progesterone [8-12]. In humans and higher primates, however, maternal, fetal, and amniotic concentrations of progesterone remain elevated during parturition and delivery, suggesting that systemic progesterone withdrawal does not occur at the initiation of labor [13-15]. Nonetheless, the administration of a synthetic progesterone antagonist, RU486, to humans at any stage of pregnancy promotes cervical ripening and parturition $[5,6,16-19]$. As such a "functional" withdrawal of progesterone action has been proposed to explain the loss of propregnancy progesterone actions despite circulating levels of progesterone remaining elevated. The exact mechanism of functional progesterone withdrawal is unclear and in recent years it has been the focus of intense research. One proposed mechanism is that functional progesterone withdrawal occurs through a decrease in myometrial responsiveness caused by a change in progesterone receptor (PR) isoform expression. Two major isoforms, PR-A and PR-B, exist in humans. PR-B is the principal transcriptional mediator of progesterone action and maintains uterine quiescence, while PR-A represses the transcriptional activity of PR-B and therefore 
decreases progesterone responsiveness [3, 5, 6, 19]. Recent work has also shown that PR-A ligand-independently stimulates the expression of the key labor promoting gene Cx43 [20]. Thus, genomic progesterone responsiveness is believed to be regulated by the opposing actions of PR-A and PR-B and is inversely associated with the PR-A/PR-B ratio $[3,5,6,19]$. Indeed, several studies, including our own, have shown that myometrial expression of $P R-A$ has significantly increased late in human pregnancy and with the onset of labor [21-24].

Elucidating the mechanism of functional progesterone withdrawal is therefore important for understanding the mechanisms regulating the balance between uterine quiescence and contractions. Outside of clinical trials, researchers are primarily limited to observational studies on human pregnancy. Interventional studies rely on animal models of pregnancy as well as on in vitro experiments using human myometrial smooth muscle cell lines and tissues. Human cell cultures are a valuable in vitro tool used to gain insight into numerous physiological and pathological processes; however, concerns have been raised about the lifespan of cultured primary cells [25] as well as their ability to remain to be representative of the tissue of origin [26-29]. The use of ex vivo myometrial tissue may represent the in vivo phenotype more closely and can involve utilizing smooth muscle biopsy samples as small pieces or dissecting the tissue into strips. Tissue strips are primarily utilized to examine myometrial contractility [30-33] such as the dynamic phosphorylation events that occur in phase with contractions $[34,35]$.

Although the use of ex vivo tissues pieces and strips has greatly facilitated studies into gene expression and regulation, both approaches rely on the assumption that the tissue phenotype remains stable across the course of the study. For instance, it is assumed that nonlaboring myometrium retains a nonlaboring phenotype ex vivo providing an experimental system to induce labor-associated changes. Myometrial strips from nonlaboring pregnant women, however, spontaneously develop contractions ex vivo over the course of just $1-2 \mathrm{~h}$, suggesting a rapid transition away from the nonlaboring in vivo phenotype $[30,33,35]$. Furthermore, tissue incubation studies are routinely performed for $48 \mathrm{~h}$ or more; therefore the transition away from the original phenotype may be even more pronounced after $48 \mathrm{~h}$ culture in vitro.

The aim of this study was to determine if nonlaboring myometrial tissue pieces and strips undergo culture-induced changes in PR expression that are consistent with transition to a PR isoform expression pattern similar to labor. We further aimed to identify culture conditions that could be implemented to block or minimize such transition in vitro, presenting researchers with a stable platform on which to conduct experimental studies.

Here we report that nonlaboring human myometrium undergoes culture-induced changes in $P R$ isoform expression in vitro comparable with the changes attributed to functional progesterone withdrawal at labor. We further report that supplementing media with the histone deacetylase inhibitor (HDACi), trichostatin A (TSA), prevents the culture-induced functional progesterone withdrawal phenomenon by maintaining a low $P R-A / P R-B$ ratio, consistent with maintenance of a nonlaboring phenotype.

\section{Materials and Methods}

2.1. Consumables and Reagents. Superscript III First-Strand Synthesis System, Ultrapure Glycogen, UltraPure Agarose, and Trackit 100 BP DNA ladder were purchased from Invitrogen (Carlsbad, USA). TRizol Reagent and Turbo DNA-free 50 reactions were from Ambion (Thermo Fisher). Alien QRT-PCR Inhibitor Alert 400 Reactions were purchased from Integrated Sciences Pty (Sydney, Australia). (R)-MG132, BAY-11-7085, Phorbol Myristate Acetate (PMA), and Prostaglandin $\mathrm{F}_{2 \alpha}\left(\mathrm{PGF}_{2 \alpha}\right)$ were obtained from Cayman Chemical Company (Michigan, USA). 8-Bromoadenosine $3^{\prime}, 5^{\prime}$-cyclic monophosphate (8-Br-cAMP), PCR primers, progesterone, and estradiol were purchased from Sigma (St Louis, USA). $2 \mathrm{~mL} 2.8 \mathrm{~mm}$ ceramic bead kits (CK28-R) for the Precellys homogenizer (Bertin Instruments, France) were purchased from Thermo Fischer Scientific (Melbourne, Australia). L-Glutamine, Sodium Pyruvate, Gentamicin, HEPES, Dulbecco's Modified Eagle Medium (DMEM), and Charcoal Stripped Fetal Bovine Serum were obtained from Gibco (Carlsbad, USA). SYBR Green 2x Master mix was from Applied Biosystems (Carlsbad, USA). TSA was supplied by Bio-Scientific Pty. Ltd. (Sydney, Australia).

2.2. Myometrial Tissue Acquisition. These studies were approved by the Hunter and New England Area Human Research Ethics Committee and the University of Newcastle Human Ethics Committee (02/06/12/3.13). Human myometrial samples were obtained from the lower uterine segment during elective Caesarean section (CS) of singleton term pregnancies (38.2-39.6 weeks' gestation). Patient body mass index (BMI) range was 18.3-38.0, and none of the patients were in-labor. The indications for elective CS were previous CS, placenta praevia, fetal distress, or breach presentation. Women were excluded if they were given steroids. Following delivery of the placenta, 5 units of syntocinon were administrated directly into an intravenous line as part of standard care for the prevention of postpartum hemorrhage. Samples were therefore exposed to oxytocin for a brief period of time $(3 \mathrm{~min})$. All samples were placed on ice in serum-free medium containing DMEM with high glucose, $2 \mathrm{mM}$ L-Glutamine, $1 \mathrm{mM}$ Sodium Pyruvate, $40 \mu \mathrm{g} / \mathrm{mL}$ Gentamicin, and $10 \mathrm{mM}$ HEPES for the transfer to the laboratory.

\subsection{Myometrial Tissue (Explant) Culture. Approximately} $100 \mathrm{mg}$ tissue from each sample was immediately snap-frozen in liquid nitrogen for subsequent analysis. The remaining myometrium was dissected into approximately $2 \times 2 \times 2 \mathrm{~mm}$ pieces and washed in serum-free media. Samples were then incubated in serum-free or $5 \%(\mathrm{v} / \mathrm{v})$ charcoal stripped serum(CSS-) supplemented media in a $37^{\circ} \mathrm{C}, 95 \%$ air $/ 5 \% \mathrm{CO}_{2}$ humidified incubator for $48 \mathrm{~h}$. The $5 \%$ CSS-supplemented media contained DMEM with high glucose, 5\% CSS, $2 \mathrm{mM} \mathrm{L-}$ Glutamine, $1 \mathrm{mM}$ Sodium Pyruvate, $40 \mu \mathrm{g} / \mathrm{mL}$ Gentamicin, and $10 \mathrm{mM}$ HEPES. To determine the effects of steroids, myometrial samples were incubated with physiological concentrations of progesterone $(\mathrm{P} 4 ; 500 \mathrm{nM})$ and/or estradiol $(\mathrm{E} 2 ; 400 \mathrm{nM})$ [14] in a $37^{\circ} \mathrm{C}, 95 \%$ air $/ 5 \% \mathrm{CO}_{2}$ humidified incubator for 48 hours. To determine the effect of stretch 
TABLE 1: CDNA primer sequences for $P R-T$ and $P R-B$.

\begin{tabular}{lccc}
\hline Primer & Primer sequence $\left(5^{\prime}-3^{\prime}\right)$ & Amplicon size & GeneBank \# \\
\hline$P R-T$ & F: GTGGGAGCTGTAAGGTCTTCTTTAA & 83 & NM000926.4 \\
& R: AACGATGCAGTCATTTCTTCCA & & \\
$P R-B$ & F: TCGGACACCTTGCCTGAAGT & & NM000926.4 \\
& R: CAGGGCCGAGGGAAGAGTAG & 68 &
\end{tabular}

$P R-T$, progesterone receptor total; $P R-B$, progesterone receptor isoform $\mathrm{B}$.

on human myometrium, myometrial tissue strips $(2 \times 2 \times$ $10 \mathrm{~mm}$ ) were cultured in 5\% CSS-containing media for $48 \mathrm{~h}$ in a $37^{\circ} \mathrm{C}, 95 \%$ air $/ 5 \% \mathrm{CO}_{2}$ humidified incubator while being subjected to 0,1 , or $3 \mathrm{~g}$ of constant stretch. Constant stretch was applied by using nylon thread to attach stainless steel weights to the ends of strips and then suspending the strips in $30 \mathrm{~mL}$ of culture media in $50 \mathrm{~mL}$ tubes (strips subjected to $0 \mathrm{~g}$ only were tied at one end). To determine the effect of stretch and steroids on human myometrium, myometrial strips were cultured in 5\% CSS-containing media with $500 \mathrm{nM} \mathrm{P} 4$ and $400 \mathrm{nM}$ E2 for $48 \mathrm{~h}$ in a $37^{\circ} \mathrm{C}, 95 \%$ air $/ 5 \% \mathrm{CO}_{2}$ humidified incubator while being subjected to 0,1 , or $3 \mathrm{~g}$ of stretch. To determine the effects of the signalling pathways involved in myometrial relaxation and contraction, myometrial tissues were incubated for $48 \mathrm{~h}$ a $37^{\circ} \mathrm{C}, 95 \%$ air $/ 5 \% \mathrm{CO}_{2}$ in $5 \%$ CSScontaining media supplemented with the cAMP analogue 8Br-cAMP $(250 \mu \mathrm{M})$, PMA $(0.1,1.0 \mu \mathrm{M}), \mathrm{PGF}_{2 \alpha}(1,10,100$, and $100 \mathrm{nM})$, or the nuclear factor $-\kappa \mathrm{B}(\mathrm{NF}-\kappa \mathrm{B})$ inhibitors MG-132 (2.0, 5.0, and 10.0 $\mu \mathrm{M})$ and BAY-11-7085 (2.0, 5.0, and $10.0 \mu \mathrm{M})$ individually or in combination (10.0 $\mu \mathrm{M}$ MG$132+10.0 \mu \mathrm{M}$ BAY-11-7085). Furthermore, myometrial tissues were incubated for $48 \mathrm{~h}$ a $37^{\circ} \mathrm{C}, 95 \%$ air $/ 5 \% \mathrm{CO}_{2}$ in $5 \%$ CSS-containing media supplemented with TSA $(0.5,1.0$, 2.5 , or $5.0 \mu \mathrm{M})$. Vehicle was DMSO $(0.1 \%)$. Following each incubation, the media were decanted and tissue pieces or strips were snap-frozen using liquid nitrogen and stored at $-80^{\circ} \mathrm{C}$ for subsequent analyses.

2.4. RNA Extraction, Reverse Transcription, and Real-Time Quantitative PCR. RNA was extracted from $100 \mathrm{mg}$ of tissue using TRizol Reagent (Thermo Fisher) according to the manufacture's protocol. Homogenization of tissue in TRizol Reagent was performed using a Precellys 24 homogenizer (Bertin Instruments, France). Following extraction, RNA samples were purified using the TURBO DNA-free kit (Thermo Fisher). An ND-1000 spectrophotometer was used to measure RNA concentration (absorbance at $260 \mathrm{~nm}\left(\mathrm{~A}_{260}\right)$ and $\left.280 \mathrm{~nm}\left(\mathrm{~A}_{280}\right)\right)$ and purity. RNA integrity was checked by agarose gel electrophoresis. Each RNA sample $(0.5 \mu \mathrm{g}$ of total RNA) was spiked with $0.5 \times 10^{7}$ copies of Alien RNA and reverse-transcribed using the SuperScript III First-Strand Synthesis System with random hexamer primers. Quantitative RT-PCR was performed using an ABI 7500 Sequence Detector. No-reverse transcription (no-RT) negative controls were prepared for each sample to ensure there was no DNA contamination. The final volume of each PCR reaction was $20 \mu \mathrm{L}$ containing $10 \mu \mathrm{L}$ of $2 x$ SYBR Green PCR Master Mix (Thermo Fisher), master mix cDNA template (corresponding to $10 \mathrm{ng}$ of reverse transcribed RNA), target cDNA-specific forward and reverse primers, and MilliQ water. For the reference gene (Alien primer), the final volume was also $20 \mu \mathrm{L}$ with $1.0 \mu \mathrm{L}$ of $2.5 \mu \mathrm{M}$ of Alien Primer Mix, $10 \mu \mathrm{L}$ of $2 x$ SYBR Green PCR, and the same amount of cDNA as the target genes and MilliQ water. No-template control samples (NTCs) were included in each PCR plate to detect any contamination and primer-dimers. PCR primers were designed using Primer Express and are shown in the Table 1.

2.5. Data and Statistical Analysis. All mRNA abundance data were expressed relative to the Alien reference RNA. The relative mRNA abundance was calculated using the delta $C_{t}$ $\left(\Delta \mathrm{C}_{\mathrm{t}}\right)$ method [36]. The relative mRNA abundance of $P R-A$ was calculated by subtracting the relative mRNA abundance of $P R-B$ from that of $P R-T$. All mRNA relative abundance values were checked for normal distribution using ShapiroWilk normality test and if data was not normally distributed, then it was logarithmically transformed to approach normal distribution. Statistical analyses were conducted with GraphPad Prism software (San Diego, CA, USA). Graphical data are presented as mean \pm SEM. For comparison between two groups, Student's $t$-test was used. For multiple comparisons, a one-way analysis of variance (ANOVA) followed by post hoc test of Dunnett multiple comparisons was used. $p$ values $\leq$ 0.05 were considered statistically significant.

\section{Results}

3.1. Culture-Induced Changes in Myometrial PR Isoform Expression over Time. Myometrial tissues were incubated for $0,1,2,6,24$, or $48 \mathrm{~h}$ in serum-free media to determine changes in $P R$ isoform expression that occurred upon being removed from the in vivo environment and cultured in vitro. $P R-T, P R$ $B$, and $P R-A$ mRNA abundance were determined across the timeline and the $P R-A / P R-B$ ratio calculated.

$P R-T$ mRNA abundance was significantly increased after 48 h culture $(p=0.0301)$ (Figure 1(a)) and was attributable to increased $P R-A$ mRNA abundance, which was significantly increased beyond 24 h culture $(p=0.0121$ ) (Figure $1(b))$. $P R-B$ mRNA abundance remained relatively constant (Figure $1(\mathrm{c})$ ). The $P R-A / P R-B$ ratio was significantly increased after $6 \mathrm{~h}$ in vitro culture $(p=0.0487)$ and highly significant beyond 24 h culture $(p<0.0001)$ (Figure $1(\mathrm{~d}))$.

3.2. Controlling Changes in PR Isoform Expression Using Serum. CSS is often used in myometrial culture media [3739]. Having observed a culture-induced increase in $P R-A$ expression (and thus $P R-T$ expression), we examined whether supplementing media with $5 \%$ CSS affected culture-induced 


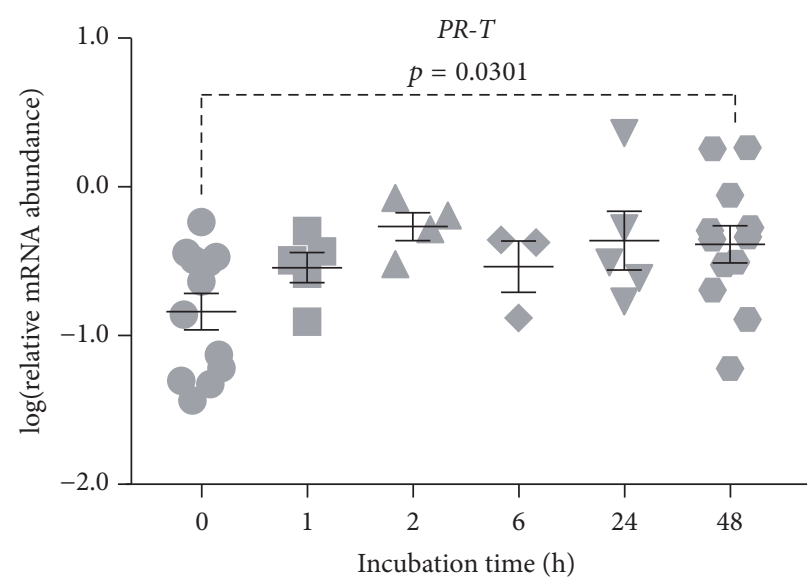

(a)

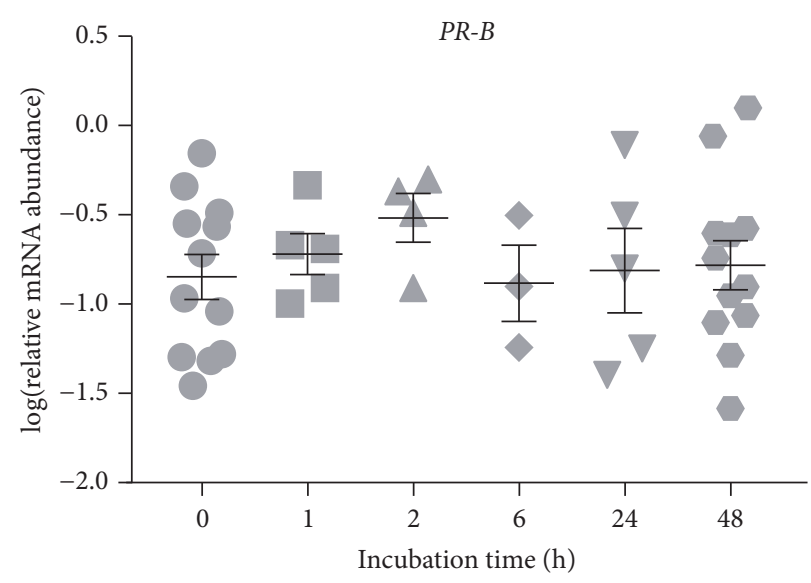

(c)

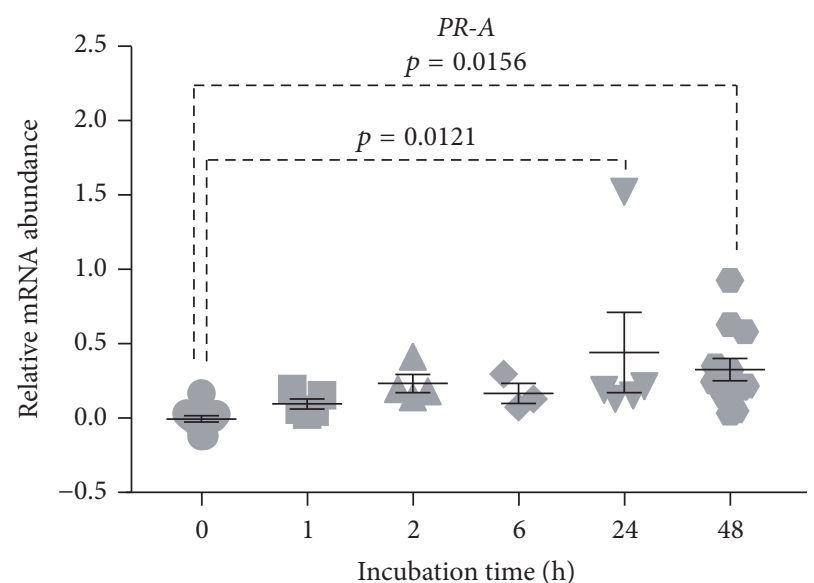

(b)

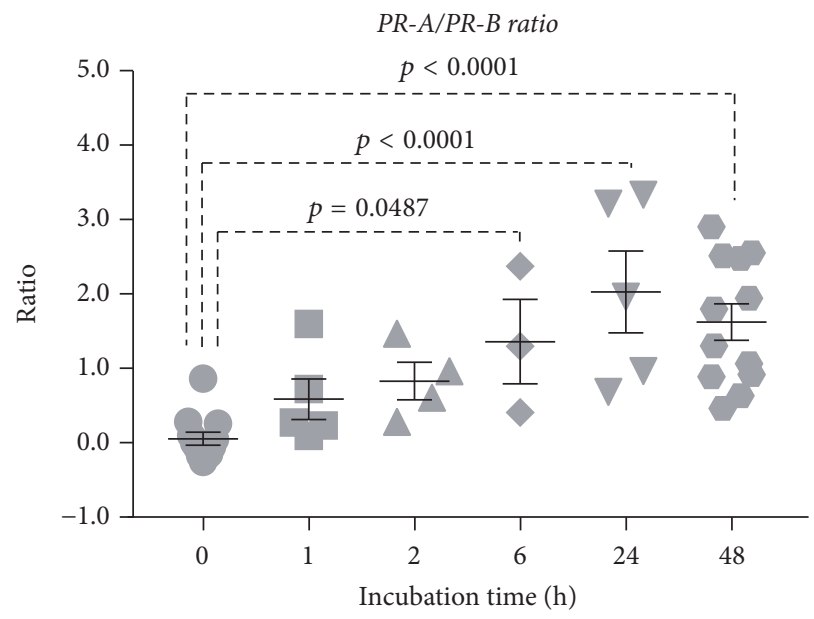

(d)

FIgURE 1: Culture-induced change in myometrial PR isoform expression over time: relative mRNA abundance of $P R-T, P R-A$, and $P R-B$ was measured in term nonlaboring myometrial tissue samples at different time points $(0,1,2,6,24$, and $48 \mathrm{~h})$, and expressed relative to Alien reference. In addition, $P R-A / P R-B$ expression ratio was calculated. (a) $P R-T$ mRNA abundance. (b) $P R-A$ mRNA abundance. (c) $P R-B$ mRNA abundance. (d) $P R-A / P R-B$ expression ratio. Data was checked for normality (Shapiro-Wilk normality test) and if necessary was logarithmically transformed to approach normal distribution (Shapiro-Wilk normality test). Data was analysed using 1-way ANOVA with multiple comparisons (Dunnett). Data are mean \pm SEM.

changes in $P R$ expression. CSS supplementation had no effect on culture-induced changes in $P R$ expression. After $48 \mathrm{~h}$ culture, there was no significant difference in $P R-T, P R-A$, or $P R-B$ mRNA abundance. Furthermore, there was no significant difference in $P R-A / P R-B$ expression ratio between myometrial tissues cultured in serum-free media versus 5\% CSSsupplemented media (Figure 2).

3.3. Controlling Changes in PR Isoform Expression Using Steroids. Relative abundance of $P R-T, P R-A$, and $P R-B$ mRNA was measured in myometrial tissues incubated for $48 \mathrm{~h}$ in the presence of $500 \mathrm{nM} \mathrm{P} 4$ or $500 \mathrm{nM} \mathrm{P} 4+400 \mathrm{nM} \mathrm{E2}$, which are hormone concentrations in term maternal plasma [14].

$P R$-T mRNA abundance significantly increased in DMSOtreated (control) tissues following $48 \mathrm{~h}$ incubation $(p=0.0317)$ (Figure 3(a)). Upon supplementing media with $500 \mathrm{nM} \mathrm{P4}$,
$P R-T$ mRNA abundance was reduced after $48 \mathrm{~h}$ culture relative to the control; however, the effect did not reach statistical significance ( $p=0.2457)$ (Figure 3(a)). Supplementing media with the combination of $500 \mathrm{nM} \mathrm{P} 4+400 \mathrm{nM}$ E2 for $48 \mathrm{~h}$ prevented the increase in $P R-T$ mRNA abundance to the extent that there was a significant difference relative to $48 \mathrm{~h}$ DMSO-treated control tissues ( $p=0.0232$ ) (Figure 3(a)).

Similarly, $P R-A$ mRNA abundance significantly increased in DMSO-treated (control) tissues following $48 \mathrm{~h}$ incubation ( $p=0.0036)$ and supplementing media with $500 \mathrm{nM} \mathrm{P} 4$ reduced $P R-A$ mRNA abundance after $48 \mathrm{~h}$ relative to the control; however, the difference was not statistically significant ( $p=0.3234)$ relative to $48 \mathrm{~h}$ DMSO-treated control tissues (Figure 3(b)). Supplementing media with the combination of $500 \mathrm{nM}$ P $4+400 \mathrm{nM}$ E2 prevented the increase in $P R-A$ mRNA abundance to the extent that there was a significant 


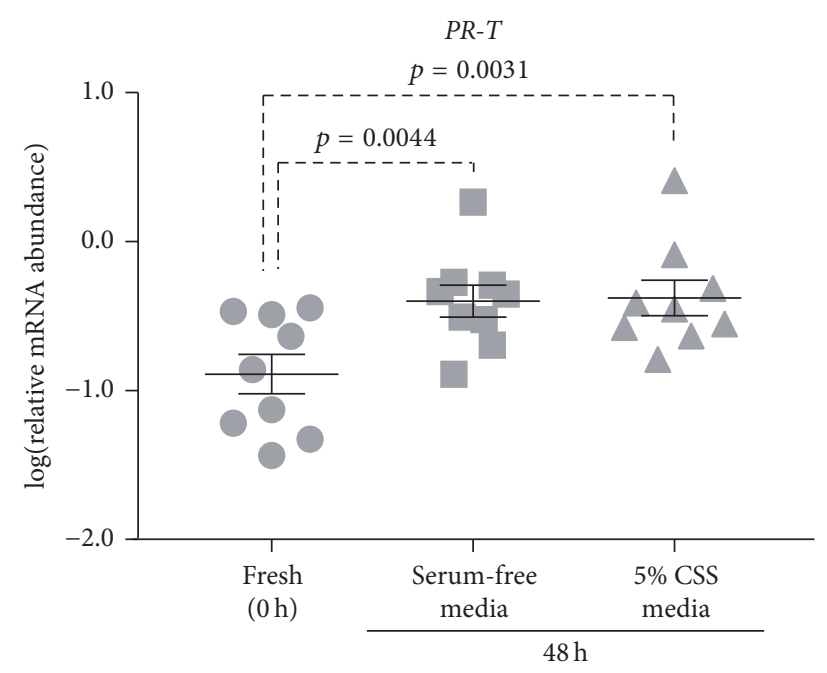

(a)

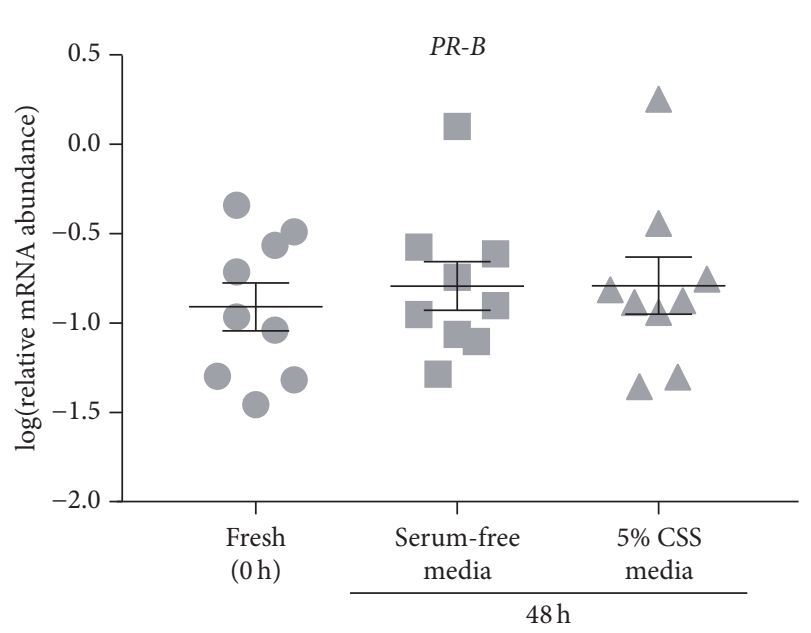

(c)

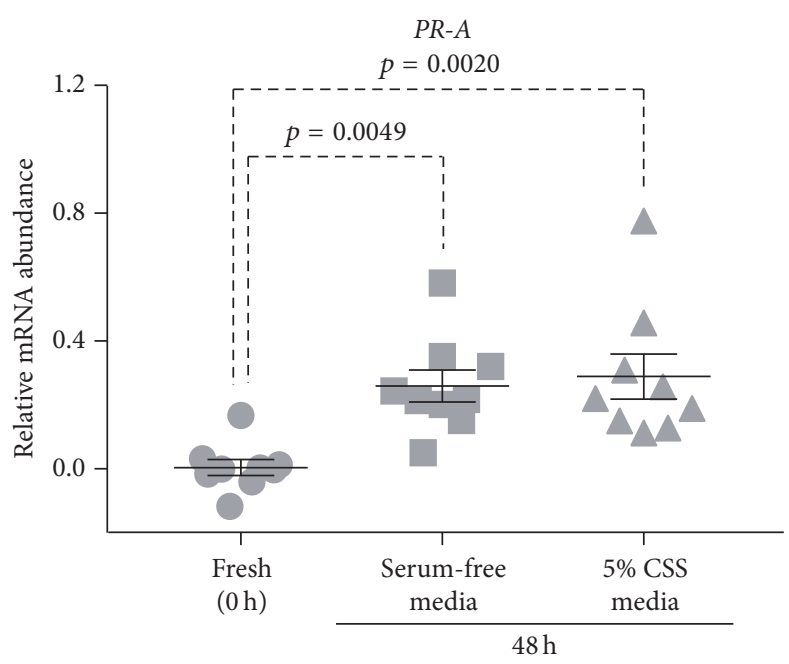

(b)

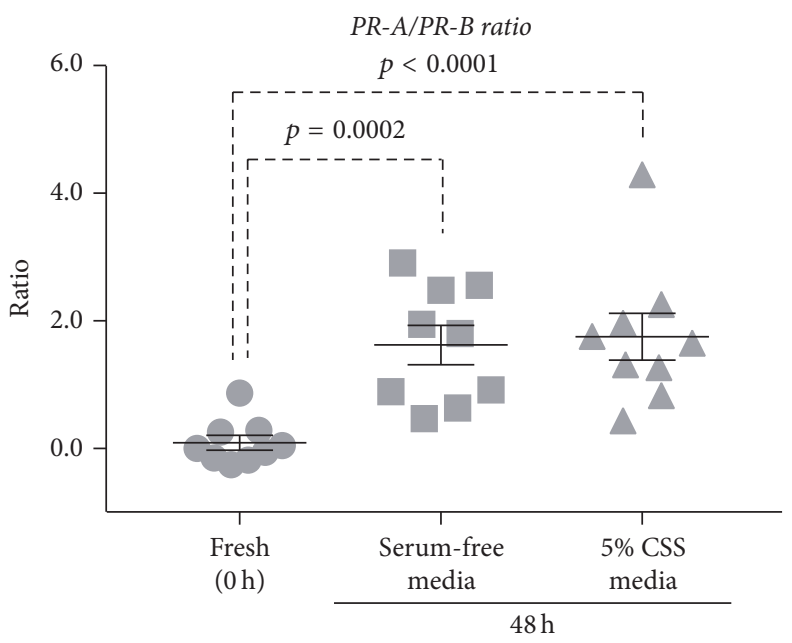

(d)

FIGURE 2: Effect of serum on culture-induced changes in PR isoform expression in vitro: relative mRNA abundance of $P R-T$, $P R-A$, and $P R-B$ was measured in term nonlaboring myometrial tissue samples following $48 \mathrm{~h}$ incubation in serum-free media or media supplemented with $5 \%$ CSS $(n=9)$ and expressed relative to Alien reference. In addition, $P R-A / P R-B$ expression ratio was calculated. (a) $P R-T$ mRNA abundance. (b) $P R-A$ mRNA abundance. (c) PR-B mRNA abundance. (d) $P R-A / P R-B$ expression ratio. Data was checked for normality (Shapiro-Wilk normality test) and if necessary was logarithmically transformed to approach normal distribution (Shapiro-Wilk normality test). Data was analysed using 1-way ANOVA with multiple comparisons (Dunnett). Data are mean \pm SEM.

difference relative to $48 \mathrm{~h}$ DMSO-treated control tissues $(p=$ 0.0175) (Figure 3(b)).

$P R-B$ mRNA abundance remained unchanged over $48 \mathrm{~h}$ of culture and supplementing media with $500 \mathrm{nM}$ P4 alone, or $500 \mathrm{nM}$ P $4+400 \mathrm{nM}$ E2, had no significant effect on $P R-B$ mRNA abundance (Figure 3(c)).

The $P R-A / P R-B$ expression ratio significantly increased in DMSO-treated (control) tissues following $48 \mathrm{~h}$ incubation $(p=0.0054)$ (Figure 3(d)). P4-supplementation had no effect on the $P R-A / P R-B$ expression ratio relative to DMSOtreated control tissues and remained significantly elevated compared to fresh tissues $(p=0.0006)$ (Figure 3(d)). Similarly, the combination of $500 \mathrm{nM}$ P4 $+400 \mathrm{nM}$ E2 had no significant effect on the $P R-A / P R-B$ expression ratio after $48 \mathrm{~h}$ relative to DMSO-treated control tissues ( $p>0.9999)$, and the $P R-A / P R-B$ expression ratio remained significantly elevated relative to the fresh tissues ( $p=0.0053$ ) (Figure 3(d)).

3.4. Controlling Changes in PR Isoform Expression Using Stretch. Myometrial tissue strips were subjected to 0,1 , or $3 \mathrm{~g}$ of stretch for $48 \mathrm{~h}$ to determine whether applying stretch to the muscle influenced culture-induced changes in $P R$ isoform expression. The effect of stretch was investigated in the absence and presence of steroids (500 nM P $4+400 \mathrm{nM}$ $\mathrm{E} 2)$.

Stretch (1 or $3 \mathrm{~g}$ ) applied to myometrial strips for $48 \mathrm{~h}$ had no effect on $P R-T$ expression (Figure 4(a)) relative to nonstretched $(0 \mathrm{~g})$ control strips. Interestingly, stretch in the presence of $500 \mathrm{nM} \mathrm{P} 4+400 \mathrm{nM}$ E2 for $48 \mathrm{~h}$ also had no significant effect on $P R-T$ mRNA levels (Figure 4(b)), 


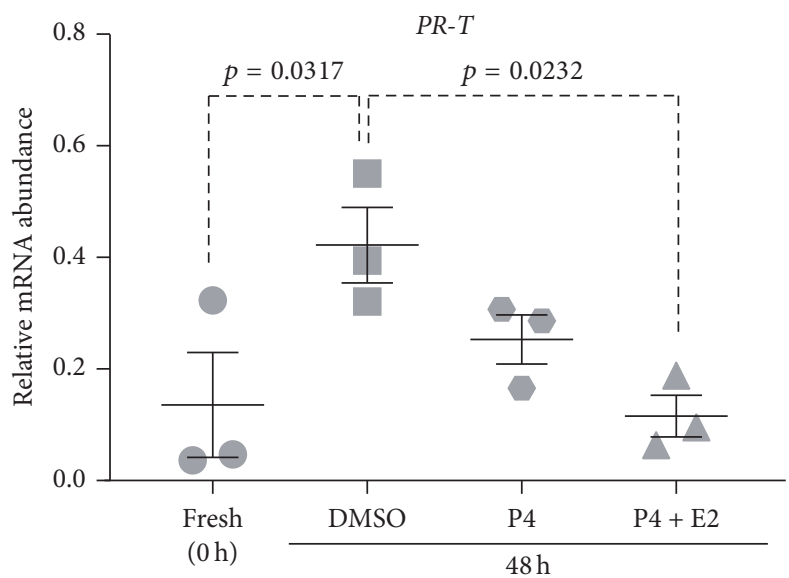

(a)

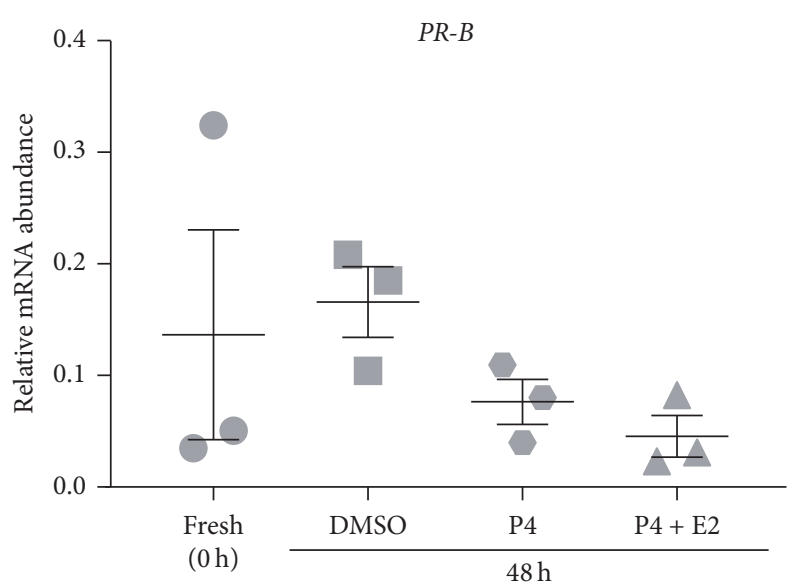

(c)

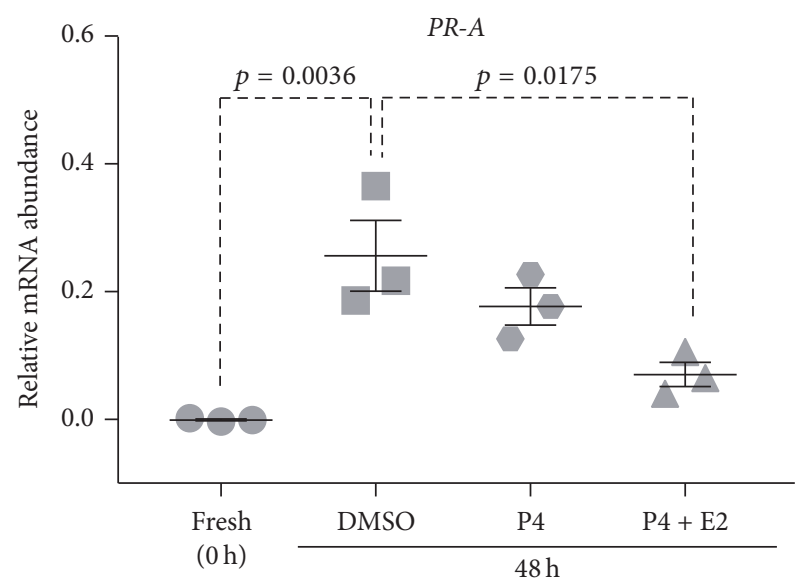

(b)

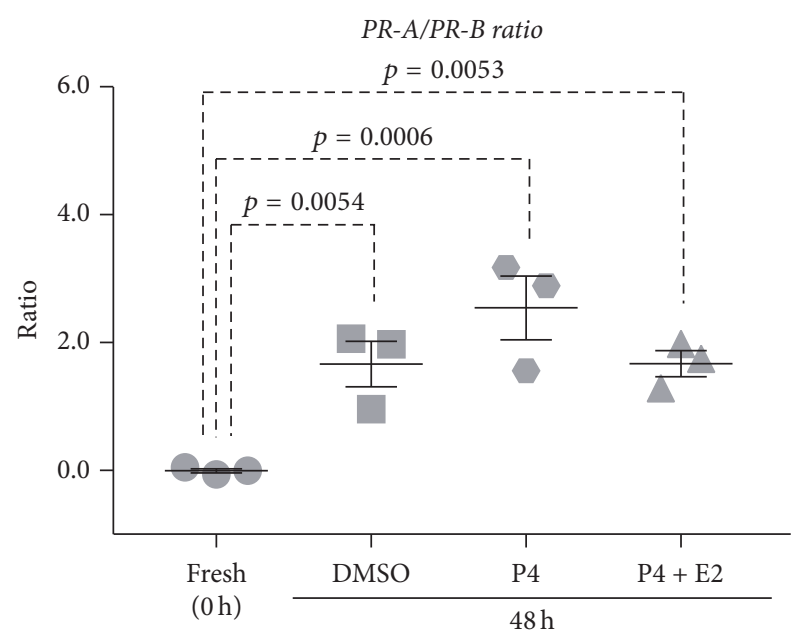

(d)

FIGURE 3: Effect of steroids on culture-induced changes in PR isoform expression in vitro: relative mRNA abundance of $P R-T, P R-A$, and $P R$ $B$ was measured in term nonlaboring myometrial tissue samples following $48 \mathrm{~h}$ incubation in the presence of $500 \mathrm{nM}$ progesterone (P4) or $500 \mathrm{nM} P 4+400 \mathrm{nM}$ estradiol (E2) $(n=3)$ and expressed relative to Alien reference. In addition, $P R-A / P R-B$ expression ratio was calculated. (a) $P R-T$ mRNA abundance. (b) $P R-A$ mRNA abundance. (c) $P R-B$ mRNA abundance. (d) $P R-A / P R-B$ expression ratio. Data was checked for normality (Shapiro-Wilk normality test) and then analysed using 1-way ANOVA with multiple comparisons (Dunnett). Data are mean \pm SEM.

indicating that $\mathrm{P} 4+\mathrm{E} 2$ was no longer effective in decreasing $P R-T$ mRNA abundance compared to fresh tissues.

Similarly, stretch applied to myometrial strips for $48 \mathrm{~h}$ had no effect on $P R-A$ mRNA expression (Figure 4(c)). Stretch applied in the presence of $500 \mathrm{nM}$ P4 + 400 nM E2 likewise had no effect (Figure 4(d)), indicating that P4 + E2 was no longer effective in preventing culture-induced increase in $P R$ A mRNA abundance compared to fresh tissues.

As seen in Figure 4(e), 0-3 g stretch had no effect on $P R$ $B$ expression in the tissue strips. Stretch in the presence of $500 \mathrm{nM}$ P $4+400 \mathrm{nM} \mathrm{E} 2$ for $48 \mathrm{~h}$ also had no significant effect on $P R-B$ mRNA levels (Figure 4(f)).

The $P R-A / P R-B$ expression ratio was calculated and there was significant increase following $48 \mathrm{~h}$ incubation in nonstretched $(0 \mathrm{~g})$ control strips when compared to fresh tissues $(p=0.0164)$ (Figure $4(\mathrm{~g})$ ). Applying stretch (1 or $3 \mathrm{~g}$ ) to myometrial strips for $48 \mathrm{~h}$ had no effect on expression ratio when compared to nonstretched strips (Figure $4(\mathrm{~g})$ ). Further, there was significant increase in $P R-A / P R-B$ expression ratio following $48 \mathrm{~h}$ incubation in nonstretched $(0 \mathrm{~g})$ control strips in the presence of $500 \mathrm{nM} \mathrm{P} 4+400 \mathrm{nM} \mathrm{E2}$ when compared to fresh tissues $(p=0.0067)$ (Figure $4(\mathrm{~h})$ ). Stretch (1 or $3 \mathrm{~g}$ ) applied in the presence of $500 \mathrm{nM} \mathrm{P} 4+400 \mathrm{nM}$ E2 had no effect on expression ratio after $48 \mathrm{~h}$ culture when compared to control strips (Figure $4(\mathrm{~h})$ ).

3.5. Controlling Changes in $P R$ Isoform Expression Using Cyclic-AMP and PMA. Relative abundance of $P R-T, P R$ $A$, and $P R-B$ mRNA was measured in myometrial tissue incubated for $48 \mathrm{~h}$ in the presence of 8-Br-cAMP $(250 \mu \mathrm{M})$, PMA (0.1 and $1.0 \mu \mathrm{M})$, or vehicle (DMSO).

Supplementing culture media with $250 \mu \mathrm{M} \mathrm{8-Br-cAMP}$ had no effect on mRNA abundance for $P R-T, P R-A$, or $P R$ $B$ (Figures 5(a)-5(c)). The $P R-A / P R-B$ expression ratio in DMSO-treated tissues was significantly elevated following $48 \mathrm{~h}$ incubation when compared to fresh tissues $(p=0.0236)$ 


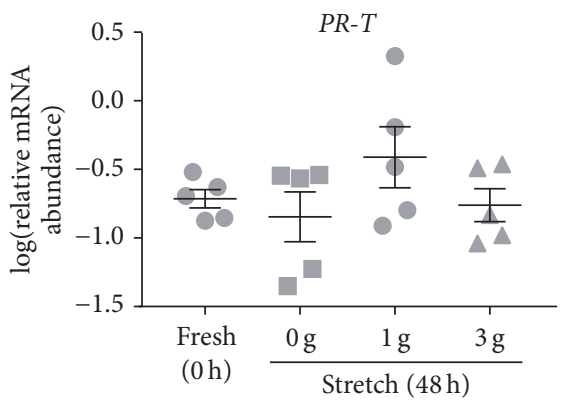

(a)

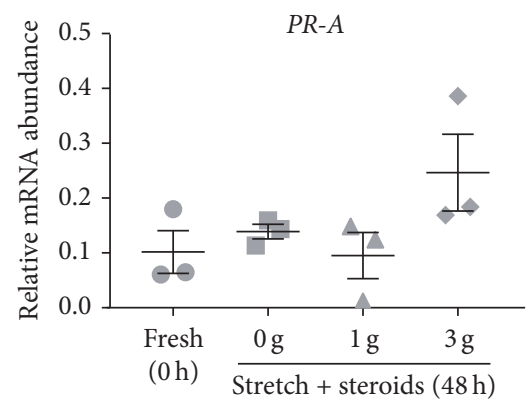

(d)

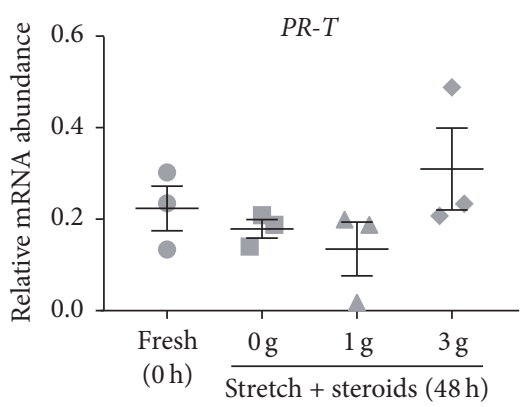

(b)

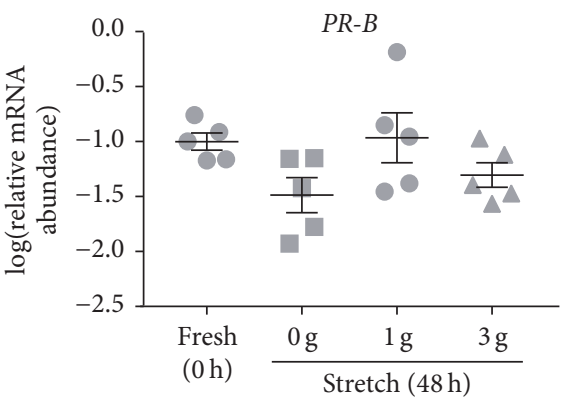

(e)

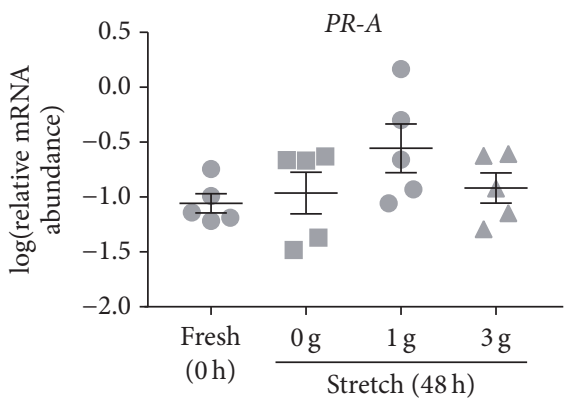

(c)

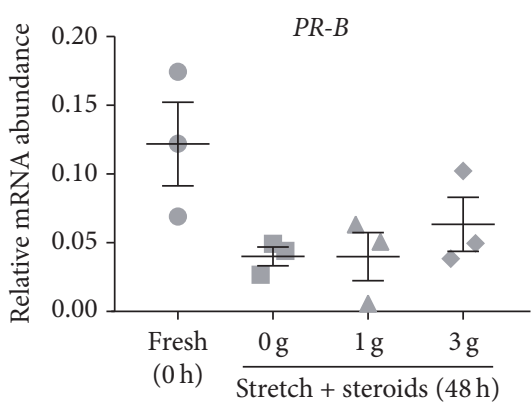

(f)

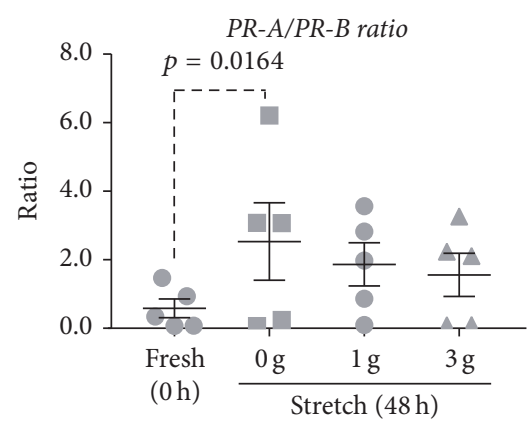

(g)

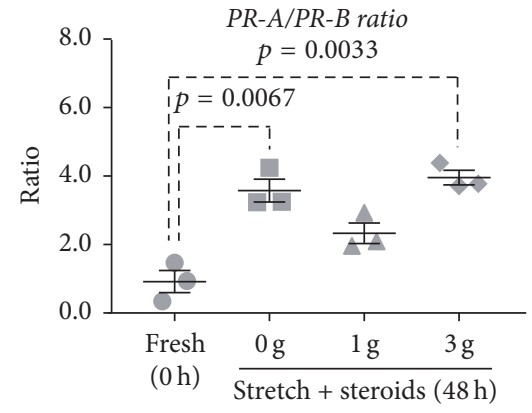

(h)

FIGURE 4: Effect of stretch in the absence or presence of steroids on culture-induced changes in PR isoform expression in vitro: Relative mRNA abundance of $P R-T, P R-A$, and $P R-B$ was measured in term nonlaboring myometrial strips while applying 0,1 , and $3 \mathrm{~g}$ of stretch for $48 \mathrm{~h}(n=5)$, as well as in presence of steroids $(500 \mathrm{nM} \mathrm{P} 4+400 \mathrm{nM} \mathrm{E} 2)$ while applying 0,1 , and $3 \mathrm{~g}$ of stretch for $48 \mathrm{~h}(n=3)$, and expressed relative to Alien reference. In addition, $P R-A / P R-B$ expression ratio was calculated. (a) Effect of stretch on $P R-T$ mRNA abundance. (b) Effect of stretch and steroids on $P R-T$ mRNA abundance. (c) Effect of stretch on $P R-A$ mRNA abundance. (d) Effect of stretch and steroids on $P R-A$ mRNA abundance. (e) Effect of stretch on $P R-B$ mRNA abundance. (f) Effect of stretch and steroids on $P R-B$ mRNA abundance. (g) Effect of stretch on $P R-A / P R-B$ expression ratio. (h) Effect of stretch and steroids on $P R-A / P R-B$ expression ratio. Data was checked for normality (Shapiro-Wilk normality test) and if necessary was logarithmically transformed to approach normal distribution (Shapiro-Wilk normality test). Data was analysed using 1-way ANOVA with multiple comparisons (Dunnett). Data are mean \pm SEM.

(Figure 5(d)). Supplementing culture media with $250 \mu \mathrm{M} 8$ Br-cAMP did not prevent the increase in the $P R-A / P R-B$ expression ratio $(p=0.0141)$ (Figure $5(d))$.

Supplementing media with 0.1 or $1.0 \mu \mathrm{M}$ PMA, a protein kinase $C(P K C)$ activator, had no significant effect on mRNA abundance for $P R-T$ or $P R-A$, relative to $48 \mathrm{~h}$ DMSOtreated control tissues (Figures 5(e) and 5(f)). PR-B mRNA abundance was reduced by both PMA treatments relative to DMSO-treated control tissues; however, the decreases did not reach statistical significance $(p=0.3659$ and $p=0.5259$, resp.) (Figure $5(\mathrm{~g})$ ). The $P R-A / P R-B$ expression ratio was significantly elevated in DMSO-treated control tissues at $48 \mathrm{~h}$, relative to fresh tissues $(p=0.0428)$ (Figure 5(h)). Supplementing media with $0.1 \mu \mathrm{M}$ PMA significantly increased the $P R-A / P R-B$ expression ratio beyond levels detected in the $48 \mathrm{~h}$ DMSO-treated control tissues $(p=0.0451)$ (Figure 5(h)) and was attributable to the, albeit nonsignificant, decline in $P R$ $B$ mRNA abundance. The $P R-A / P R-B$ expression ratio was significantly elevated after $48 \mathrm{~h}$ in $1.0 \mu \mathrm{M}$ PMA-treated tissues compared to fresh tissues $(p=0.0023)$ (Figure 5(h)).

3.6. Controlling Changes in PR Isoform Expression Using $P G F_{2 \alpha}$. Relative abundance of $P R-T, P R-A$, and $P R-B$ mRNA 


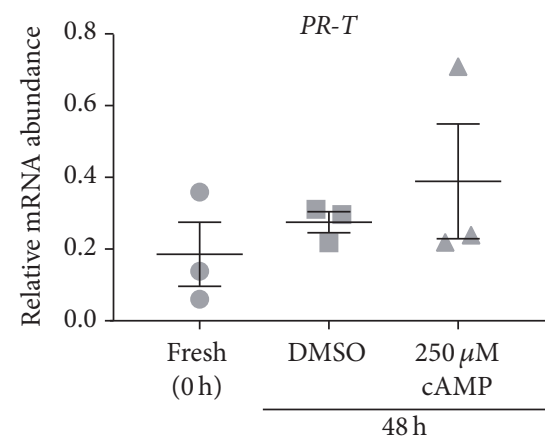

(a)

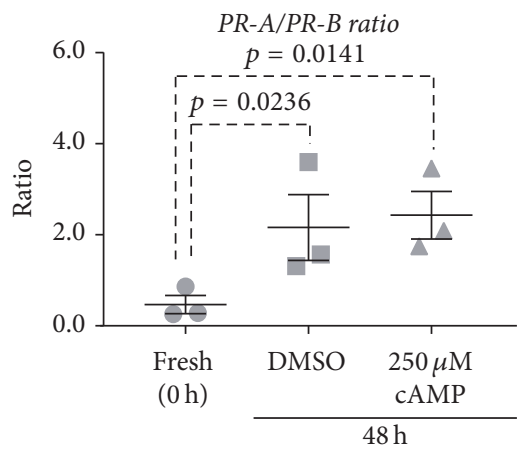

(d)

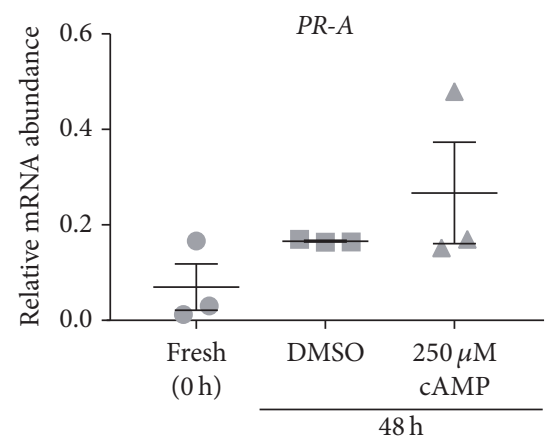

(b)

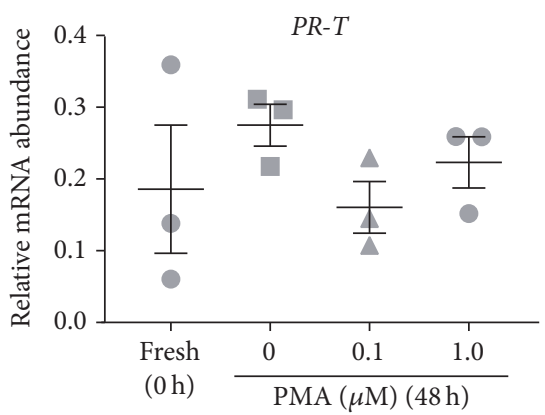

(e)

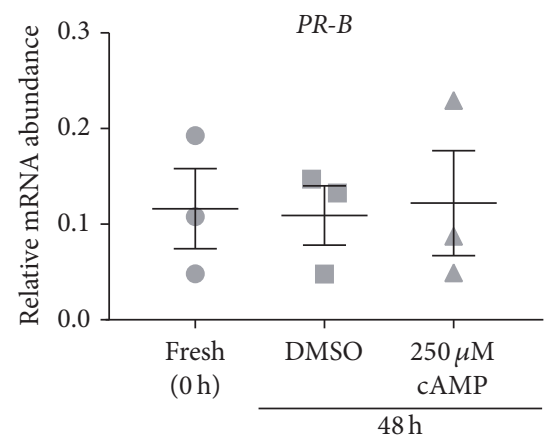

(c)

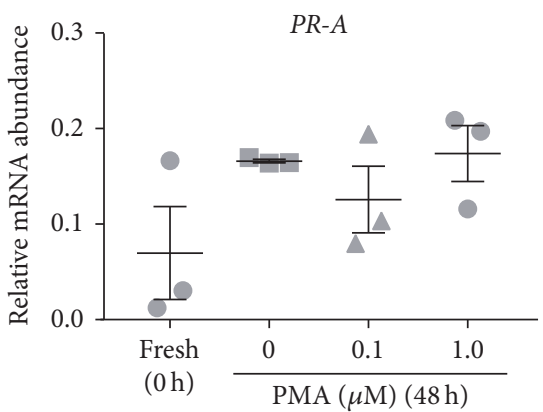

(f)

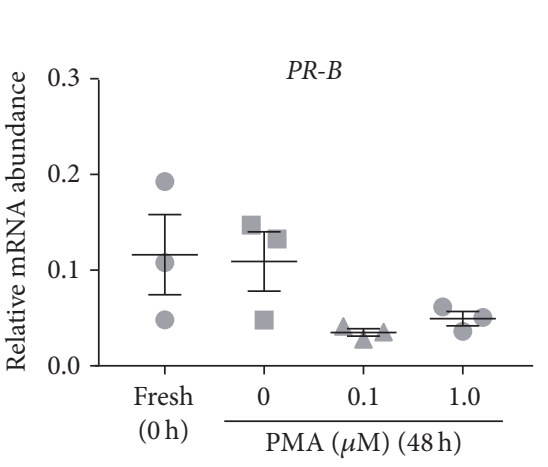

(g)

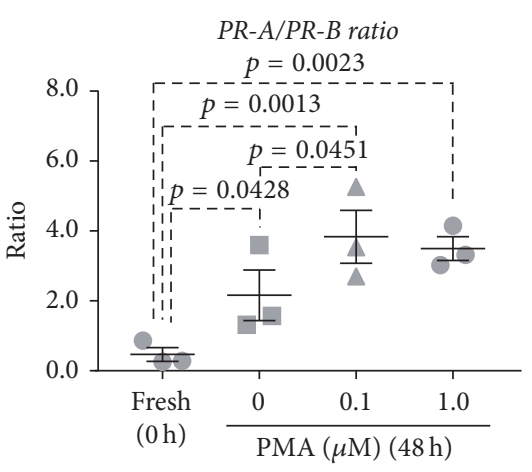

(h)

FIGURE 5: Effect of cAMP and PMA on culture-induced changes in PR isoform expression in vitro: Relative mRNA abundance of $P R$ - $T$, $P R-A$, and $P R-B$ was measured in term nonlaboring myometrial tissue samples $(n=3)$ following $48 \mathrm{~h}$ incubation in the presence of 8 -Br-cAMP $(250 \mu \mathrm{M})$ or PMA $(0.1$ and $1.0 \mu \mathrm{M})$ and expressed relative to Alien reference. In addition, $P R-A / P R-B$ expression ratio was calculated. (a) Effect of 8-Br-cAMP on $P R$ - $T$ mRNA abundance. (b) Effect of 8-Br-cAMP on $P R-A$ mRNA abundance. (c) Effect of 8-Br-cAMP on $P R-B$ mRNA abundance. (d) Effect of 8-Br-cAMP on $P R-A / P R-B$ expression ratio. (e) Effect of PMA on $P R-T$ mRNA abundance. (f) Effect of PMA on $P R-A$ mRNA abundance. (g) Effect of PMA on PR-B mRNA abundance. (h) Effect of PMA on PR-A/PR-B expression ratio. Data was checked for normality (Shapiro-Wilk normality test) and then analysed using 1-way ANOVA with multiple comparisons (Dunnett). Data are mean \pm SEM.

was measured in myometrial tissue incubated for $48 \mathrm{~h}$ in the presence of $\mathrm{PGF}_{2 \alpha}(1,10,100$, or $1000 \mathrm{nM})$ or vehicle (DMSO).

Following $48 \mathrm{~h}$ incubation $P R-T$ mRNA abundance in DMSO-treated control tissues was elevated relative to fresh tissues but did not reach statistical significance (Figure 6(a)). $\mathrm{PGF}_{2 \alpha}$ treatments had no effect on PR-T mRNA abundance relative to $48 \mathrm{~h}$ DMSO-treated control tissues (Figure 6(a)).

$P R-A$ mRNA abundance was significantly increased in DMSO-treated control tissues relative to fresh tissues $(p=0.0451)$ (Figure 6(b)). PGF $_{2 \alpha}$ treatments had no effect on PR-A mRNA abundance relative to $48 \mathrm{~h}$ DMSO-treated control tissues (Figure 6(b)).

$P R-B$ mRNA abundance remained unchanged following $48 \mathrm{~h}$ incubation and was not affected by $\mathrm{PGF}_{2 \alpha}$ treatments (Figure 6(c)).

In $48 \mathrm{~h}$ DMSO-treated tissue the $P R-A / P R-B$ expression ratio was significantly elevated relative to fresh tissues $(p=$ 0.0294 ) (Figure $6(\mathrm{~d})$ ). $\mathrm{PGF}_{2 \alpha}$ supplementation $(1,10,100$, or 


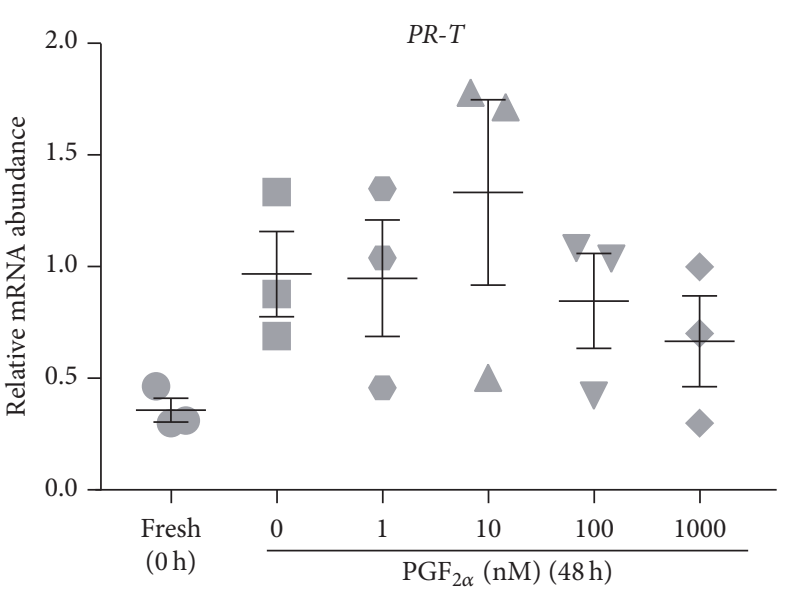

(a)

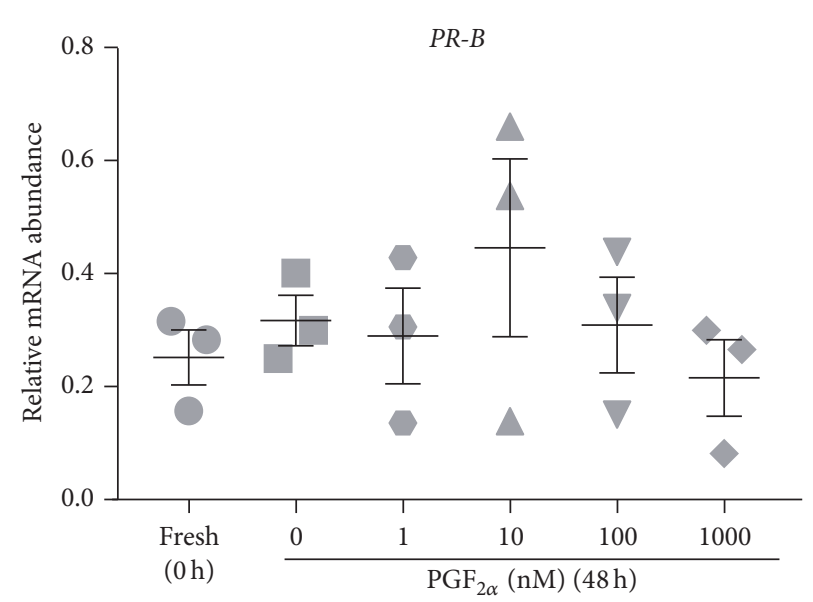

(c)

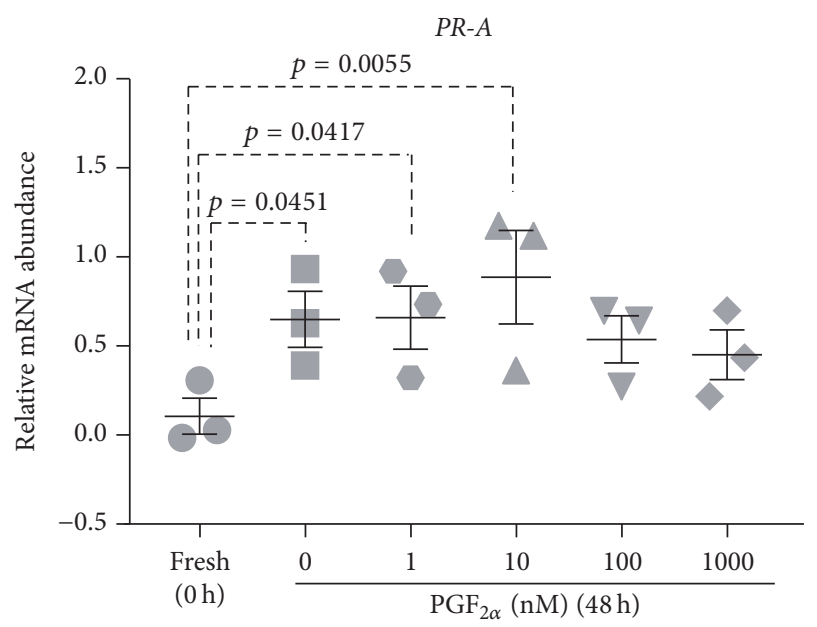

(b)

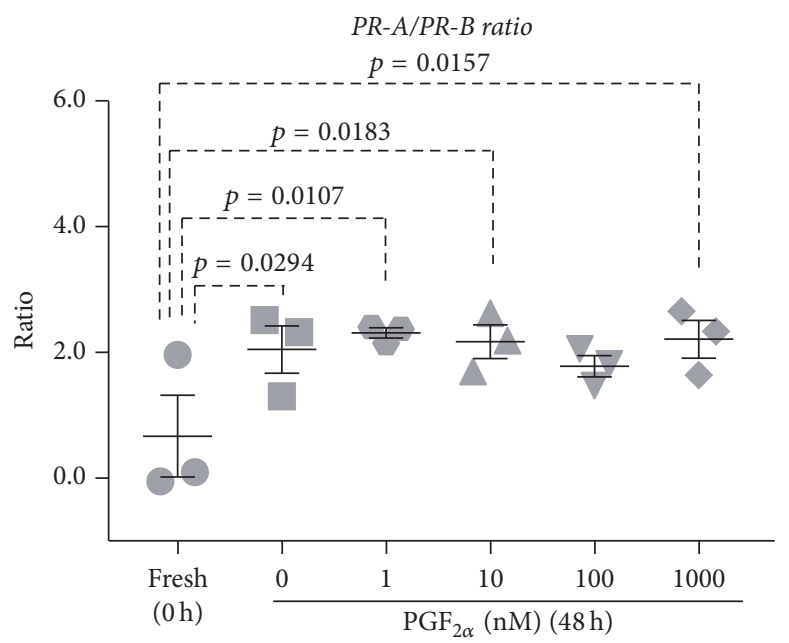

(d)

FIGURE 6: Effect of $P_{G F}$ on culture-induced changes in PR isoform expression in vitro: relative mRNA abundance of $P R-T, P R-A$, and $P R-B$ was measured in term nonlaboring myometrial tissue samples $(n=3)$ following $48 \mathrm{~h}$ incubation in the presence of $\mathrm{PGF}{ }_{2 \alpha}(1,10,100$, and $1000 \mathrm{nM}$ ) and expressed relative to Alien reference. In addition, $P R-A / P R-B$ expression ratio was calculated. (a) $P R-T$ mRNA abundance. (b) $P R-A$ mRNA abundance. (c) PR-B mRNA abundance. (d) $P R-A / P R-B$ expression ratio. Data was checked for normality (Shapiro-Wilk normality test) and then analysed using 1-way ANOVA with multiple comparisons (Dunnett). Data are mean \pm SEM.

$1000 \mathrm{nM})$ had no effect on the $P R-A / P R-B$ expression ratio relative to DMSO-treated control tissues (Figure 6(d)).

\subsection{Controlling Changes in PR Isoform Expression Using} $N F-\kappa B$ Inhibitors. The NF- $\kappa$ B inhibitors, MG-132 and BAY11-7085, were employed to test whether NF- $\kappa$ B pathway activation was involved in the $P R$ isoform expression changes induced by in vitro culture.

Following $48 \mathrm{~h}$ incubation, there was no significant difference in $P R-T$ mRNA abundance between vehicle-treated tissues and fresh tissues (Figure 7(a)). Incubating myometrial samples with $2.0,5.0$, or $10.0 \mu \mathrm{M}$ MG-132 or BAY-11-7085 individually or in combination ( $10 \mu \mathrm{M}$ each) had no effect on $P R-T$ mRNA abundance relative to vehicle-treated tissues (Figure 7(a)).
$P R-A$ mRNA abundance in vehicle-treated tissues significantly increased compared to fresh tissues following $48 \mathrm{~h}$ incubation $(p=0.0170)$ (Figure $7(b))$. Supplementing culture media with 2.0, 5.0, or $10.0 \mu \mathrm{M}$ MG-132 or BAY-11-7085 individually or in combination $(10 \mu \mathrm{M}$ each) had no significant effect on PR-A mRNA abundance relative to $48 \mathrm{~h}$ vehicle-treated tissues (Figure $7(\mathrm{~b})$ ).

Following $48 \mathrm{~h}$ incubation, there was no significant difference in $P R-B$ mRNA abundance between vehicle-treated tissues and fresh tissues (Figure $7(\mathrm{c})$ ). Incubating myometrial samples with $2.0,5.0$, or $10.0 \mu \mathrm{M}$ MG-132 or BAY-11-7085 individually or in combination ( $10 \mu \mathrm{M}$ each) had no effect on $P R-B$ mRNA abundance relative to vehicle-treated tissues (Figure 7(c)).

Following $48 \mathrm{~h}$ incubation, the $P R-A / P R-B$ expression ratio was significantly elevated in vehicle-treated tissues 


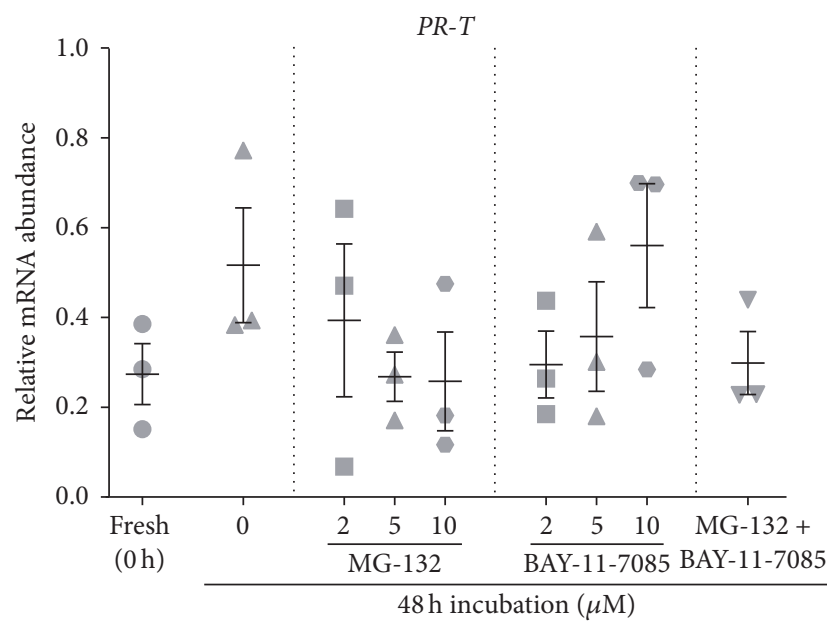

(a)

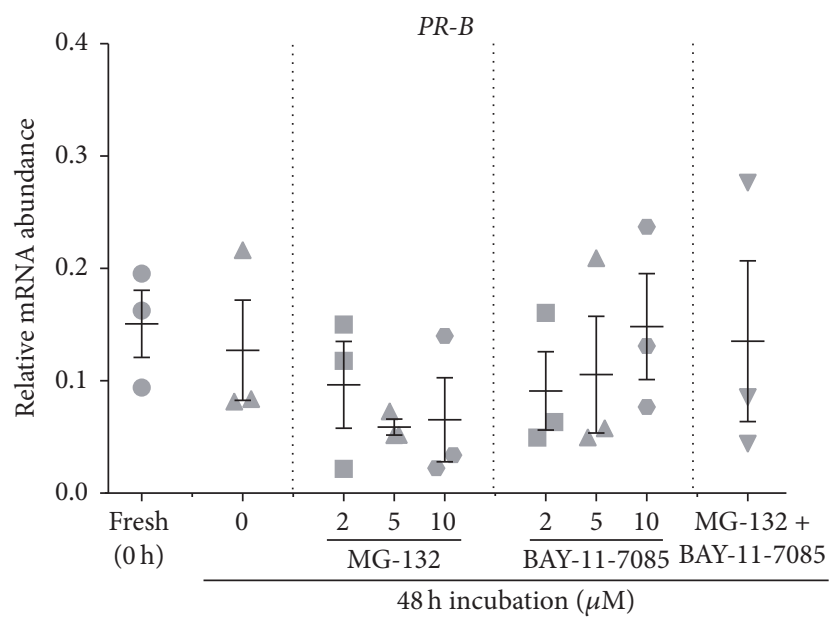

(c)

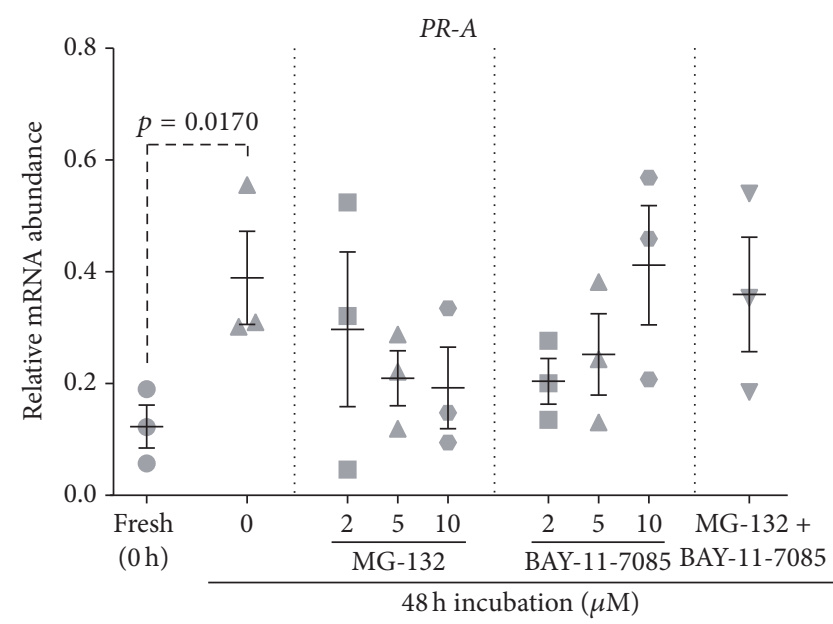

(b)

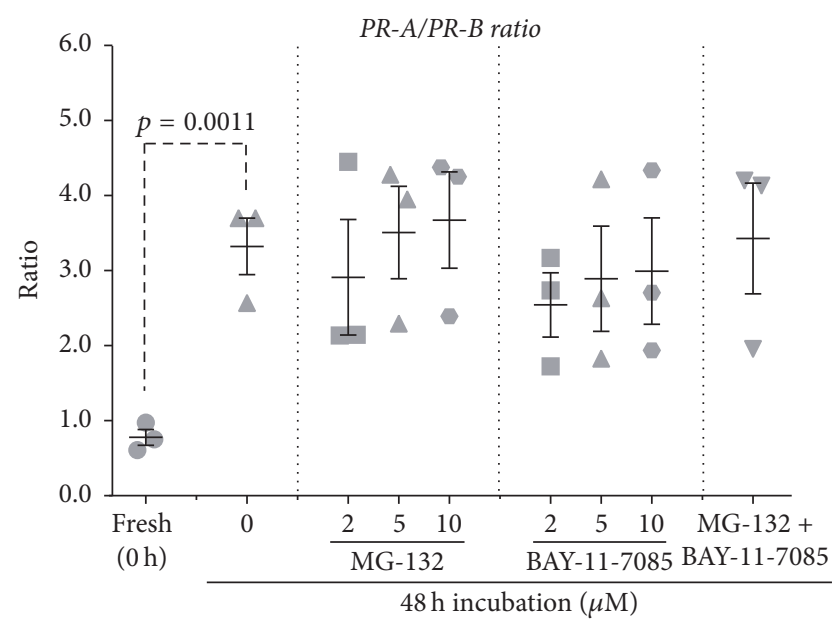

(d)

FIGURE 7: Effect of NF- $\kappa$ B inhibitors, MG-132 and BAY-11-7085, on culture-induced changes in PR isoform expression in vitro: relative mRNA abundance of $P R-T, P R-A$, and $P R-B$ was measured in term nonlaboring myometrial samples $(n=3)$ following $48 \mathrm{~h}$ incubation in the presence of different NF- $\kappa$ B inhibitors and expressed relative to Alien reference RNA. In addition, $P R-A / P R-B$ expression ratio was calculated. (a) $P R-T$ mRNA abundance. (b) $P R-A$ mRNA abundance. (c) $P R-B$ mRNA abundance. (d) $P R-A / P R-B$ expression ratio. Data was checked for normality (Shapiro-Wilk normality test) and then analysed using 1-way ANOVA with multiple comparisons (Dunnett). Data are mean \pm SEM.

compared to fresh tissues $(p=0.0011)$ (Figure $7(d))$. Supplementing culture media with $2.0,5.0$, or $10.0 \mu \mathrm{M}$ MG-132 or BAY-11-7085 individually or in combination (10 $\mu \mathrm{M}$ each) had no effect on $P R-A / P R-B$ expression ratio compared to the vehicle-treated tissues (Figure 7(d)).

3.8. Controlling Changes in PR Isoform Expression Using TSA. Relative abundance of $P R-T, P R-A$, and $P R-B$ mRNA was measured in myometrial tissue incubated for $48 \mathrm{~h}$ in the presence of TSA $(0.5,1.0,2.5$, and $5.0 \mu \mathrm{M})$ or vehicle (DMSO).

There was no significant difference in $P R-T$ mRNA abundance between $48 \mathrm{~h}$ vehicle-treated tissues and fresh tissues (Figure 8(a)). Incubating myometrial samples with 0.5, 1.0, 2.5, and $5.0 \mu \mathrm{M}$ TSA had no effect $P R-T$ mRNA abundance relative to $48 \mathrm{~h}$ vehicle-treated tissues (Figure $8(\mathrm{a})$ ).

$P R-A$ mRNA abundance was significantly increased in $48 \mathrm{~h}$ vehicle-treated tissues relative to fresh tissues $(p=0.0431)$
(Figure 8(b)). Culture-induced increases in $P R-A$ mRNA abundance were inhibited by supplementing media with TSA. The extent of inhibition reached statistical significance, relative to $48 \mathrm{~h}$ vehicle-treated tissue, at $5.0 \mu \mathrm{M}$ TSA ( $p=$ 0.0305) (Figure 8(b)).

$P R-B$ mRNA abundance did not change following $48 \mathrm{~h}$ incubation and was unaffected by TSA treatments relative to vehicle-treated tissues (Figure 8(c)).

Following $48 \mathrm{~h}$ incubation, the $P R-A / P R-B$ expression ratio was significantly elevated in vehicle-treated tissues compared to fresh tissues $(p=0.0002$ ) (Figure $8(\mathrm{~d})$ ). The $P R-A / P R-B$ expression ratio was significantly lower in tissue treated with 2.5 and $5.0 \mu \mathrm{M}$ TSA $(p=0.0003$ and $p<0.0001$, resp.) relative to $48 \mathrm{~h}$ vehicle-treated tissues (Figure $8(\mathrm{~d})$ ). TSA dose-dependently prevented culture-induced increases in the $P R-A / P R-B$ expression ratio. 


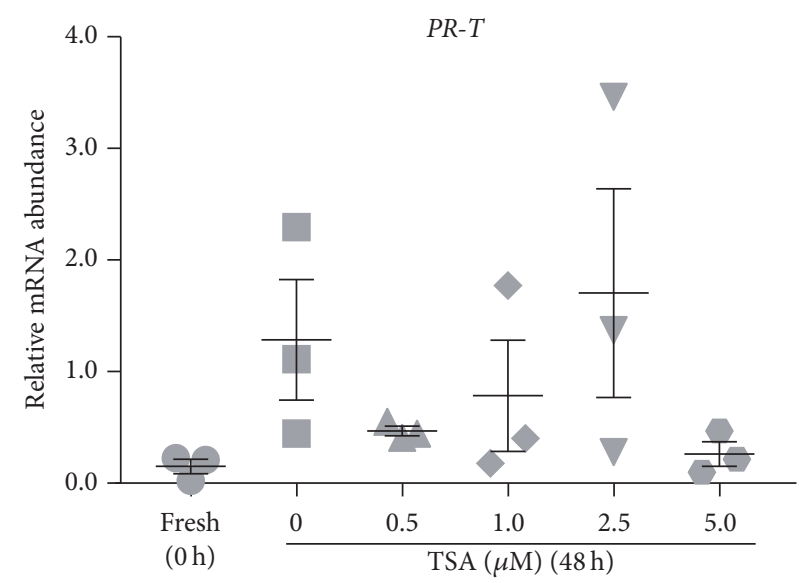

(a)

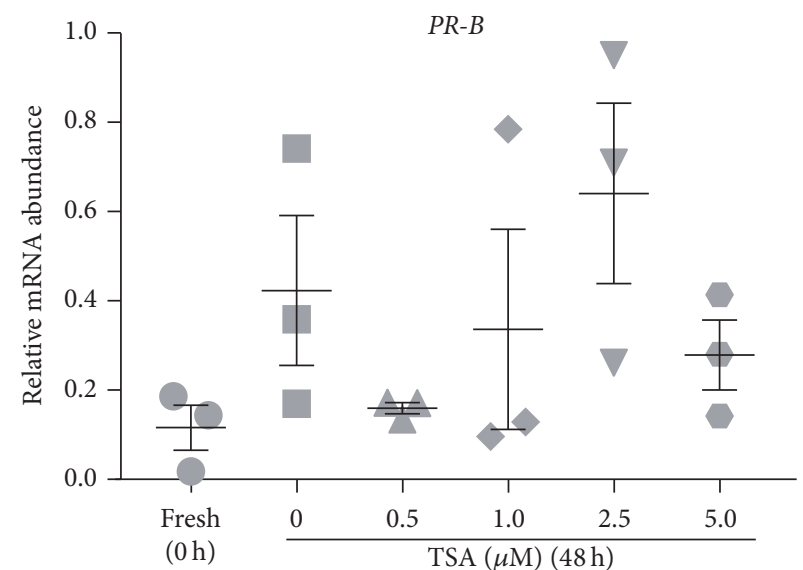

(c)

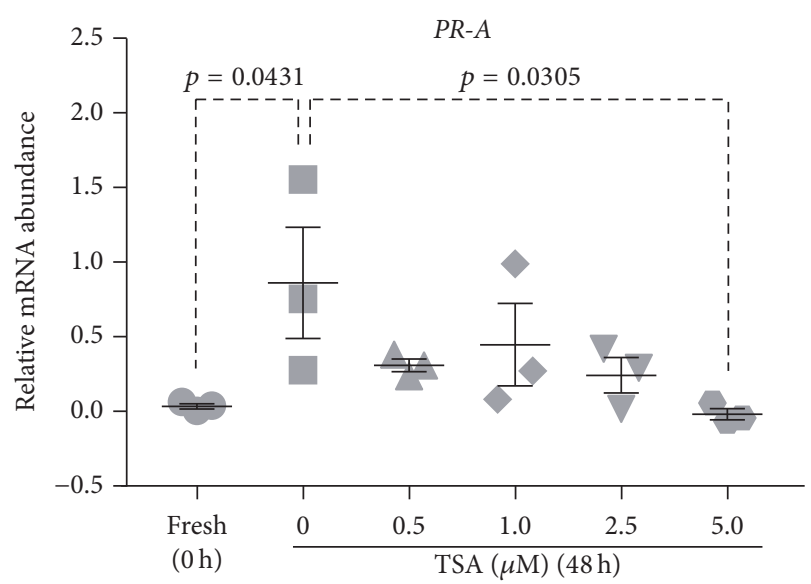

(b)

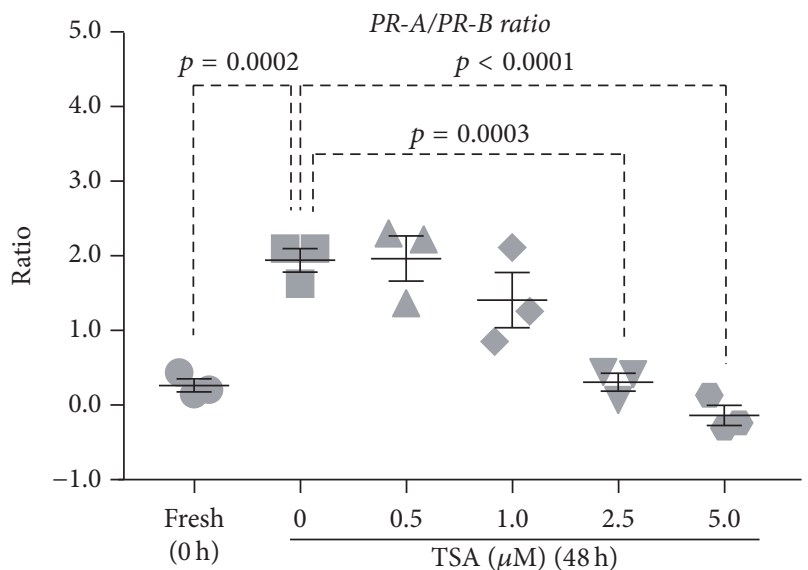

(d)

FIGURE 8: Effect of TSA on culture-induced changes in PR isoform expression in vitro: relative mRNA abundance of $P R-T, P R-A$, and $P R-B$ was measured in term nonlaboring myometrial tissue samples $(n=3)$ following $48 \mathrm{~h}$ incubation in the presence of TSA $(0.5,1.0,2.5$, and $5.0 \mu \mathrm{M}$ ) and expressed relative to Alien reference. In addition, $P R-A / P R-B$ expression ratio was calculated. (a) $P R-T$ mRNA abundance. (b) $P R-A$ mRNA abundance. (c) $P R-B$ mRNA abundance. (d) $P R-A / P R-B$ expression ratio. Data was checked for normality (Shapiro-Wilk normality test) and then analysed using 1-way ANOVA with multiple comparisons (Dunnett). Data are mean \pm SEM.

\section{Discussion}

Human tissue and cell cultures are a valuable in vitro tool used to investigate the maintenance of uterine quiescence and the mechanisms by which the myometrium transforms to an actively contracting organ at labor. Our previous results show that, upon culturing nonlaboring myometrial tissues in vitro, the tissue undergoes culture-induced changes in expression of the key myometrial genes ESR1, PTGS2, and OXTR, which are consistent with transition toward a procontractile, laboring phenotype (under review). In light of this evidence, we further examined whether $P R$ isoform expression undergoes culture-induced changes that are consistent with transition to a procontractile, laboring phenotype.

In this study we examined changes in $P R$ isoform expression via determining mRNA levels, an approach which is consistent with other studies in the field [40]. Nevertheless, we are aware that PR isoform protein levels may reflect PR function more closely than mRNA abundance especially in pregnancies complicated by intrauterine inflammation [41]. Previous studies have demonstrated, however, that there is close correspondence between $\mathrm{PR}$ isoform mRNA and protein expression changes in the human myometrium at normal term labor $[23,24]$, which is the context of this study. Furthermore, recent studies examining protein profiles in mammalian cells have found that transcription, not translation, mostly determines protein abundance [42] and that during periods of dynamic change, such as phenotype transition, changes in mRNA abundance play a dominant role in determining changes in protein levels [43]. Overall, assessing myometrial PR function by determining $P R-A$ and $P R-B$ mRNA levels appears a reliable approach in the patient population we examined.

Tissue incubation studies are routinely performed for $48 \mathrm{~h}$ or more $[38,39,44]$. Considering that nonlaboring human myometrium develops contractility in vitro in just $1-2 \mathrm{~h}[30,33,35,45]$, the transition away from the original phenotype may be even more pronounced after such $48 \mathrm{~h}$ 
incubations. Our results illustrate that, in human myometrial pieces, $P R-A$ mRNA abundance begins increasing after just $1 \mathrm{~h}$ culture. With $P R-B$ mRNA abundance remaining constant, a statistically significant increase in the $P R-A / P R-B$ expression ratio was evident after just $6 \mathrm{~h}$ culture (Figure 1). Previous studies using enzyme-immunoassays found that samples collected from the upper segment myometrium during labor had higher total PR concentrations than samples collected prior to labor [46]. Haluska et al. [22] used rhesus monkey, another genus that lacks a systemic progesterone withdrawal, to look at the changes in PR isoform concentrations. They found that there was no change in total PR expression during the transition from late pregnancy to labor; however, they did find a significant shift in the ratio of $P R$ isoforms [22]. More specifically, the myometrial $P R-A / P R-B$ ratio increased significantly from late pregnancy to spontaneous labor at term [22]. Furthermore, Pieber et al. [47] performed immunoblot analyses on lower segment myometrium from pregnant women and reported an increase in the PR-A protein abundance during labor, while levels of PR-B were not altered by labor status. Recently, our group showed that the onset of labor is associated with increased abundance of $P R-A$ mRNA and an increase in the $P R-A / P R-B$ expression ratio in term human myometrium [24]. Our group has also found that the PR-A/PR-B protein ratio in pregnant human myometrium was 0.5 (a PR-B dominant state) at 30 weeks' gestation, which then increased to 1.0 at term prior to the onset of labor, and at the time of the labor the ratio increased further to 3.0 (a PR-A dominant state) [23]. These results indicate that $P R$ mRNA levels reflect $P R$ protein levels in human myometrium. Our observation that $P R-T$ and $P R-A$ mRNA abundance as well as the $P R-A / P R-B$ expression ratio increased during culture is therefore consistent with the tissue transitioning to a labor-like state as a consequence of in vitro conditions.

This finding has implications for the interpretation in vitro of studies performed on nonlaboring myometrium, which may have in fact already transitioned to a labor-like phenotype during the early stages of the study and may therefore have affected the outcome of the study. To address this, we sought to identify culture conditions that could be implemented to maintain a nonlaboring state whereby human myometrium retained a low $P R-A / P R-B$ expression ratio (a $P R-B$ dominant state), thereby providing a more appropriate in vitro model for conducting studies into myometrial bio$\log$.

Previous studies utilizing myometrial culture (explants) often included CSS in their media [37-39]. Therefore, we examined whether supplementing culture media with 5\% CSS affected culture-induced changes in $P R$ isoform expression. Surprisingly, 5\% CSS had no significant effect on $P R$ $T, P R-A$, or $P R-B$ mRNA abundance after $48 \mathrm{~h}$ culture and consequently had no effect on the $P R-A / P R-B$ expression ratio (Figure 2). While supplementing media with serum is common practice during in vitro culture, our results indicate that this practice is not sufficient to prevent culture-induced changes in $P R$ isoform expression.

The steroid hormone progesterone plays a crucial role in maintaining pregnancy by promoting myometrial quiescence and relaxation [5-7]. In contrast to most mammalian species [8-12], no decrease in maternal serum levels of progesterone can be observed in humans and higher primates prior to the onset of labor [13-15]. Thus, the term "functional progesterone withdrawal" has been used to describe the withdrawal of progesterone action. Once myometrial tissue is removed from in vivo environment and cultured in vitro, the high plasma levels of progesterone are no longer present, which could possibly account for culture-induced changes in $P R$ expression in vitro. To explore this, we incubated myometrial tissues in media that contained physiological concentrations of progesterone. Supplementing media with progesterone alone was not sufficient to prevent the culture-induced increases in $P R-T$ and $P R-A$ mRNA abundance. Moreover, progesterone decreased $P R-B$ mRNA abundance; however it was not statistically significant; nevertheless this further exacerbated the increase in the $P R-A / P R-B$ expression ratio (Figure 3). A previous study using myometrial strips showed that progesterone exerts rapid inhibition of the amplitude of myometrial contractions in vitro [30]. More recently, Baumbach et al. [31] investigated the suppression of uterine contractility using progesterone alone and in a combination with various tocolytics and found that progesterone alone had little effect inhibiting contractility [31]. This is consistent with our results where progesterone alone did not prevent cultureinduced increases in PR-T and PR-A mRNA abundance.

In numerous mammalian species, the process of parturition, especially transformation of the myometrium from the quiescent to a contractile state, necessitates an increase in circulating estrogen concentrations prior to the onset of labor $[11,14,48,49]$. In humans and higher primates, however, maternal estrogen levels are high for most of pregnancy and remain elevated during parturition and delivery [14, 50, 51]. Furthermore, our group reported a correlation between estrogen receptor 1 (ESR1) mRNA levels and the $P R-A / P R-B$ mRNA ratio, which is indicative of a functional link between the PR and ESR1 systems [24]. In addition, this link between the two systems is in agreement with studies performed in a range of species demonstrating that progesterone decreases expression of ESR1, thus decreasing uterine responsiveness to estrogen $[52,53]$. These results imply that the interaction between progesterone and PR-B suppresses ESR1 expression, therefore rendering the myometrium refractory to circulating estrogen [19]. However, with advancing gestation there is an increase in the expression of PR-A, which in turn represses the transcriptional activity of $\mathrm{PR}-\mathrm{B}$, and as a result the PRB-mediated inhibition of ESR1 expression is withdrawn [19]. Once myometrial tissue is removed from in vivo environment and cultured in vitro, the high plasma levels of progesterone and estrogen are no longer present, thereby removing the functional link between progesterone and estrogen [24] which could possibly account for the observed cultureinduced changes in $P R$ expression in vitro. To explore this, we incubated myometrial tissue in media that contained physiological concentrations of P4 and E2. The combination of $\mathrm{P} 4$ and $\mathrm{E} 2$ prevented culture-induced increase in $P R-T$ and $P R-A$ mRNA abundance observed in vitro. However, $\mathrm{P} 4$ in combination with $\mathrm{E} 2$ also decreased $P R-B$ mRNA abundance; nevertheless this decrease was not statistically significant. 
As such, after $48 \mathrm{~h}$ culture the $P R-A / P R-B$ expression ratio had still increased relative to fresh tissue and adopted a $P R-A$ dominant state (Figure 3).

Throughout normal pregnancy the uterus increases several-fold in size by both hyperplasia and hypertrophy to accommodate the growing fetus and placenta [54, 55]. A previous study using term nonlaboring human myometrium tissue showed that stretch applied to myometrial cells in culture resulted in decreased $P R-T$ and $P R-B$ mRNA expression [56]. We found that constant stretch, applied by means of hanging 1 or $3 \mathrm{~g}$ weights from tissue strips, had no effect on culture-induced changes in PR isoform expression (Figure 4). This is inconsistent with a previous report where stretch downregulated $P R-T$ and $P R-B$ expression; however, it should be noted that those studies used myometrial cells while our study uses myometrial tissue strips [56]. Previous animal studies suggest that progesterone is responsible for maintaining uterine quiescence and promoting myometrial hyperplasia and hypertrophy to inhibit any increase in uterine wall tension [57-60]. In addition, human studies show that, in a progesterone-dominated endocrine environment, moderate stretch possibly maintains relaxation and quiescence; however, in the absence of progesterone or excessive stretch, the uterus starts to contract $[54,55]$. Interestingly, although stretch did not directly affect the culture-induced changes in $P R-T, P R-A$, or $P R-B$ expression, the application of stretch prevented steroids $(\mathrm{P} 4+\mathrm{E} 2)$ from blocking culture-induced increases in $P R-T$ and $P R-A$ mRNA expression and prevented steroids (P4 + E2) from decreasing $P R-B$ mRNA expression (Figures 3 and 4).

There is now extensive evidence to suggest that components of the cAMP signalling pathway are upregulated in the human myometrium throughout pregnancy to maintain uterine quiescence until term [61-65]. Moreover, our group showed that, in PHM1-31 cells, a pregnant human myometrial cell line, 8-Br-cAMP, an agonist for the protein kinase A (PKA) pathway, increased the expression of both $P R-A$ and $P R-B$ but had a net effect of decreasing the $P R-A / P R-B$ expression ratio [66]. Supplementing media with a cAMP analogue was therefore examined as a potential means to prevent culture-induced changes in $P R$ isoform expression. Although cAMP has a well-defined role in promoting myometrial relaxation, supplementing media with 8 -Br-cAMP failed to prevent culture-induced changes in $P R-T$ or $P R-A$ mRNA abundance and increased $P R-A / P R-B$ expression ratio (Figure 5).

In contrast to previously discussed treatments that attempted to prevent culture-induced changes in $P R$ isoform expression, we also examined the effect of the procontractile agent, PMA, to determine whether $P R$ expression would be driven further toward a labor-like state. Previous studies by our group show that PKC activation by PMA increased the $P R-A / P R-B$ expression ratio by selectively increasing expression of $P R-A$ [66]. This study found that supplementing culture with PMA further increased the $P R-A / P R-B$ expression ratio in vitro, which was consistent with this procontractile agent driving further transition toward a laboring phenotype. Interestingly, PMA did not increase expression of $P R-A$ but rather decreased expression of $P R-B$ over the course of the myometrial culture (Figure 5).

There is increasing evidence that locally produced immune/inflammatory cytokines, particularly prostaglandins (PGs), are involved in normal term labor as well as infection-associated preterm labor [67-69]. In human pregnancy, administration of PGs or PG analogues at any stage of pregnancy transforms the myometrium and cervix and induces labor [69-73]. Previously, our group has tested the hypothesis that PGs, specifically $\mathrm{PGF}_{2 \alpha}$, induce functional progesterone withdrawal by altering myometrial $P R$ expression in PHM1-31 cells [66]. PGF $_{2 \alpha}$ produced a dosedependent increase in expression of $P R-A$, but not $P R-B$, thereby resulting in an increase in the $P R-A / P R-B$ expression ratio [66]. In this study, supplementing media with $\mathrm{PGF}_{2 \alpha}$ had no effect on $P R$ mRNA abundance and therefore did not prevent culture-induced changes in the $P R-A / P R-B$ expression ratio (Figure 6). This is not consistent with previous results where $\mathrm{PGF}_{2 \alpha}$ increased the $P R-A / P R-B$ expression ratio by increasing PR-A expression [66].

Romero et al. [74] have shown that tissue-level inflammation in the myometrium, decidua, and fetal membranes plays a crucial role in the human parturition. In recent years, studies have demonstrated that myometrium in pregnant women at term exhibits biochemical and histological characteristics of inflammation, including increased expression of PGs, increased NF- $\kappa \mathrm{B}$ activity, increased infiltration of neutrophils, and macrophages, which may precede the onset of active labor and is independent of infection $[6,8,75-$ 80]. Furthermore, studies using human myometrial cells have shown that progesterone inhibits the proinflammatory NF$\kappa \mathrm{B}$ transcription factor complex as a result of $\mathrm{PR}$-induced expression of inhibitor $-\kappa \mathrm{B}-\alpha$ (NFKB1A), a major NF- $\kappa \mathrm{B}$ repressor [81]. Supplementing media with NF- $\kappa$ B inhibitors therefore represented a potential means of preventing spontaneous changes in $P R$ isoform expression. Supplementing media with MG-132 or BAY-11-7085 had no effect on PR-T, $P R-A$, and $P R-B$ mRNA abundance and therefore did not prevent culture-induced changes in the $P R-A / P R-B$ expression ratio (Figure 7 ).

Condon et al. [82] administered TSA, a specific and potent HDACi, to pregnant mice late in gestation and found increased histone $\mathrm{H} 3$ acetylation as well as a delay in the initiation of parturition by $24-48 \mathrm{~h}$. Decreased histone acetylation in the pregnant uterus near term, caused by a marked decrease in expression of uterine coactivators with intrinsic histone acetyltransferase activity, might serve an important role in the loss of PR function, thus instigating a functional progesterone withdrawal and the initiation of labor [82]. Furthermore, Wilson et al. [83] used the mouse mammary tumor virus promoter to examine the impact of TSA on PR activated transcription and found that TSA removed the transcription factor nuclear factor 1 from the promoter and decreased PR-induced transcription [83]. Based on these results we hypothesised that TSA may modulate $P R$ isoform expression and supplemented culture media with TSA in anticipation of maintaining a low $P R-A / P R-B$ expression ratio in vitro. Excitingly, TSA produced a dose-dependent inhibition of culture-induced upregulation of $P R-A$ mRNA 
abundance. With no effect of $P R-B$ mRNA abundance, TSA was successful in maintaining a low $P R-A / P R-B$ expression ratio over $48 \mathrm{~h}$ culture, consistent with freshly isolated term nonlaboring myometrium and consistent with preventing in vitro transformation to a laboring phenotype (Figure 8). Using TSA to maintain a low $P R-A / P R-B$ ratio could have important clinical ramifications in that progesterone therapy is currently a leading strategy for the prevention of preterm birth (reviewed by van Zijl et al. [84]). Efficacy of progesterone administration may be enhanced if an agent such as TSA could be administered to preserve or even restore progesterone sensitivity in women with threatened preterm labor.

\section{Conclusion}

Concerns have previously been raised about the ability of primary cells in culture to remain representative of their tissues of origin. Adding to this concern, our previous study shows that term nonlaboring human myometrial tissue undergoes culture-induced changes in expression of ESR1, PTGS2, and $O X T R$ that are consistent with transitioning toward a laboring phenotype. In this study we examined $P R$ isoform expression and found that $P R-T$ and $P R-A$ mRNA expression increased in untreated tissue over $48 \mathrm{~h}$ culture. Additionally, the $P R$ $A / P R-B$ expression ratio significantly increased, consistent with transition to a laboring phenotype. Through examining various culture conditions, we were able to maintain a nonlaboring state of PR isoform expression by supplementing culture media with TSA, which prevented the cultureinduced increase in $P R-A$ mRNA abundance and maintained a low $P R-A / P R-B$ expression ratio. In summary, this study demonstrates that

(i) human myometrial tissues undergo culture-induced upregulation of $P R-T$ and $P R-A$ mRNA expression, which significantly increases the $P R-A / P R-B$ expression ratio in vitro, even in nontreated tissue;

(ii) the combination of progesterone and estrogen downregulated $P R-T$ and $P R-A$ mRNA expression;

(iii) stretch had no direct effect on $P R-T, P R-A$, or $P R-B$ expression, but it blocked the effects of progesterone and estrogen on $P R-T$ and $P R-A$ expression;

(iv) cAMP was unable to control culture-induced changes in $P R$ expression;

(v) PMA further upregulated $P R-A / P R-B$ expression ratio;

(vi) $\mathrm{PGF}_{2 \alpha}$ had no effect of $P R$ expression in vitro;

(vii) NF- $\kappa \mathrm{B}$ inhibitors were unable to control cultureinduced changes in $P R$ expression;

(viii) TSA downregulated $P R-A$ mRNA expression and downregulated $P R-A / P R-B$ expression ratio.

\section{Disclosure}

The funding providers had no involvement in the study or production of this article.

\section{Conflicts of Interest}

The authors declare that there are no conflicts of interest.

\section{Authors' Contributions}

Marina Ilicic, Tamas Zakar, and Jonathan W. Paul conceived and designed the experiments. Marina Ilicic contributed to sample collection. Marina Ilicic and Jonathan W. Paul performed the experiments and contributed to data analysis and manuscript writing. Tamas Zakar and Jonathan W. Paul provided reagents and materials. Tamas Zakar contributed to manuscript editing.

\section{Acknowledgments}

This work was supported by grants from the National Health and Medical Research Council, Australia (NHMRC), the John Hunter Hospital Charitable Trust (JHHCT), and School of Medicine and Public Health Research Training Scheme (RTS). Facilities and infrastructure were provided by the University of Newcastle and Hunter Medical Research Institute (HMRI). The authors wish to thank the obstetricians from the John Hunter Hospital, NSW, their research midwife, Anne Wright, and the research participants who donated samples toward this study.

\section{References}

[1] J. R. G. Challis, D. M. Sloboda, N. Alfaidy et al., "Prostaglandins and mechanisms of preterm birth," Reproduction, vol. 124, no. 1, pp. 1-17, 2002.

[2] J. M. Dodd and C. A. Crowther, "The role of progesterone in prevention of preterm birth," International Journal of Women's Health, vol. 1, no. 1, pp. 73-84, 2010.

[3] S. Mesiano, "Myometrial progesterone responsiveness," Seminars in Reproductive Medicine, vol. 25, no. 1, pp. 5-13, 2007.

[4] S. C. Tough, "Preterm Birth and Healthy Outcomes Team: the science and strategy of team-based investigation," BMC Pregnancy and Childbirth, vol. 13, article S1, 2013.

[5] P. Arck, P. J. Hansen, B. M. Jericevic, M.-P. Piccinni, and J. Szekeres-Bartho, "Progesterone during pregnancy: endocrineimmune cross talk in Mammalian Species and the role of stress," American Journal of Reproductive Immunology, vol. 58, no. 3, pp. 268-279, 2007.

[6] S. Astle, D. M. Slater, and S. Thornton, "The involvement of progesterone in the onset of human labour," European Journal of Obstetrics Gynecology and Reproductive Biology, vol. 108, no. 2, pp. 177-181, 2003.

[7] A. Csapo, "Progesterone block," American Journal of Anatomy, vol. 98, no. 2, pp. 273-291, 1956.

[8] V. C. Allport, D. Pieber, D. M. Slater, R. Newton, J. O. White, and P. R. Bennett, "Human labour is associated with nuclear factor$\kappa \mathrm{B}$ activity which mediates cyclo-oxygenase- 2 expression and is involved with the 'functional progesterone withdrawal,' Molecular Human Reproduction, vol. 7, no. 6, pp. 581-586, 2001.

[9] G. Liggins, "Initiation of Labour," Neonatology, vol. 55, no. 6, pp. 366-375, 1989.

[10] G. C. Liggins, R. J. Fairclough, S. A. Grieves, J. Z. Kendall, and B. S. Knox, "The mechanism of initiation of parturition in the ewe," Recent Prog Horm Res, vol. 29, pp. 111-159, 1973. 
[11] S. Mesiano, "Myometrial progesterone responsiveness and the control of human parturition," Journal of the Society for Gynecologic Investigation, vol. 11, no. 4, pp. 193-202, 2004.

[12] I. R. Young, "The comparative physiology of parturition in mammals," Front Horm Res, vol. 27, pp. 10-30, 2001.

[13] R. S. Boroditsky, F. I. Reyes, J. S. Winter, and C. Faiman, "Maternal serum estrogen and progesterone concentrations preceding normal labor," Obstet Gynecol, vol. 51, no. 6, pp. 686-91, 1978.

[14] D. Tulchinsky, C. J. Hobel, E. Yeager, and J. R. Marshall, "Plasma estrone, estradiol, estriol, progesterone, and 17-hydroxyprogesterone in human pregnancy. I. Normal pregnancy," American Journal of Obstetrics and Gynecology, vol. 112, no. 8, pp. 10951100, 1972.

[15] S. W. Walsh, F. Z. Stanczyk, and M. J. Novy, "Daily hormonal changes in the maternal, fetal, and amniotic fluid compartments before parturition in a primate species," The Journal of Clinical Endocrinology \& Metabolism, vol. 58, no. 4, pp. 629-639, 1984.

[16] O. M. Avrech, A. Golan, Z. Weinraub, I. Bukovsky, and E. Caspi, "Mifepristone (RU486) alone or in combination with a prostaglandin analogue for termination of early pregnancy: a review," Fertility and Sterility, vol. 56, no. 3, pp. 385-393, 1991.

[17] X. Fang, S. Wong, and B. F. Mitchell, "Effects of RU486 on estrogen, progesterone, oxytocin, and their receptors in the rat uterus during late gestation," Endocrinology, vol. 138, no. 7, pp. 27632768, 1997.

[18] G. J. Haluska, C. A. Kaler, M. J. Cook, and M. J. Novy, "Prostaglandin production during spontaneous labor and after treatment with RU486 in pregnant rhesus macaques," Biology of Reproduction, vol. 51, no. 4, pp. 760-765, 1994.

[19] S. Mesiano and T. N. Welsh, "Steroid hormone control of myometrial contractility and parturition," Seminars in Cell and Developmental Biology, vol. 18, no. 3, pp. 321-331, 2007.

[20] L. Nadeem, O. Shynlova, E. Matysiak-Zablocki, S. Mesiano, X. Dong, and S. Lye, "Molecular evidence of functional progesterone withdrawal in human myometrium," Nature Communications, vol. 7, article 11565, 2016.

[21] P. H. Giangrande and D. P. McDonnell, "The A and B isoforms of the human progesterone receptor: two functionally different transcription factors encoded by a single gene," Recent Prog Horm Res, vol. 54, pp. 291-314, 1999.

[22] G. J. Haluska, T. R. Wells, J. J. Hirst, R. M. Brenner, D. W. Sadowsky, and M. J. Novy, "Progesterone receptor localization and isoforms in myometrium, decidua, and fetal membranes from rhesus macaques: evidence for functional progesterone withdrawal at parturition," Journal of the Society for Gynecologic Investigation, vol. 9, no. 3, pp. 125-136, 2002.

[23] A. A. Merlino, T. N. Welsh, H. Tan et al., "Nuclear progesterone receptors in the human pregnancy myometrium: evidence that parturition involves functional progesterone withdrawal mediated by increased expression of progesterone receptor-A," Journal of Clinical Endocrinology and Metabolism, vol. 92, no. 5, pp. 1927-1933, 2007.

[24] S. Mesiano, E.-C. Chan, J. T. Fitter, K. Kwek, G. Yeo, and R. Smith, "Progesterone withdrawal and estrogen activation in human parturition are coordinated by progesterone receptor A expression in the myometrium," Journal of Clinical Endocrinology and Metabolism, vol. 87, no. 6, pp. 2924-2930, 2002.

[25] L. Hayflick and P. S. Moorhead, "The serial cultivation of human diploid cell strains," Experimental Cell Research, vol. 25, no. 3, pp. 585-621, 1961.

[26] A. G. Bodnar, M. Ouellette, M. Frolkis et al., "Extension of lifespan by introduction of telomerase into normal human cells," Science, vol. 279, no. 5349, pp. 349-352, 1998.
[27] P. Chapdelaine, J. Kang, S. Boucher-Kovalik, N. Caron, J. P. Tremblay, and M. A. Fortier, "Decidualization and maintenance of a functional prostaglandin system in human endometrial cell lines following transformation with SV40 large T antigen," Molecular Human Reproduction, vol. 12, no. 5, pp. 309-319, 2006.

[28] N. Perez-Reyes, C. L. Halbert, P. P. Smith, E. P. Benditt, and J. K. McDougall, "Immortalization of primary human smooth muscle cells," Proceedings of the National Academy of Sciences, vol. 89, no. 4, pp. 1224-1228, 1992.

[29] J. Qian, E. M. Hendrix, W. J. Larsen, G. W. Dorn II, and J. L. Lessard, "Establishment and characterization of a conditionally immortalized smooth muscle/myometrial-like cell line," Molecular Reproduction and Development, vol. 47, no. 3, pp. 284-294, 1997.

[30] L. Anderson, W. Martin, C. Higgins, S. M. Nelson, and J. E. Norman, "The effect of progesterone on myometrial contractility, potassium channels, and tocolytic efficacy," Reproductive Sciences, vol. 16, no. 11, pp. 1052-1061, 2009.

[31] J. Baumbach, S.-Q. Shi, L. Shi, J. Balducci, D. V. Coonrod, and R. E. Garfield, "Inhibition of uterine contractility with various tocolytics with and without progesterone: in vitro studies," American Journal of Obstetrics and Gynecology, vol. 206, no. 3, pp. 254.e1-254.e5, 2012.

[32] N. K. Ruddock, S.-Q. Shi, S. Jain et al., "Progesterone, but not 17alpha-hydroxyprogesterone caproate, inhibits human myometrial contractions," American Journal of Obstetrics and Gynecology, vol. 199, no. 4, pp. 391.el-391.e7, 2008.

[33] E. K. Tyson, R. Smith, and M. Read, "Evidence that corticotropin-releasing hormone modulates myometrial contractility during human pregnancy," Endocrinology, vol. 150, no. 12, pp. 5617-5625, 2009.

[34] C. A. Hudson, K. J. Heesom, and A. L. Bernal, "Phasic contractions of isolated human myometrium are associated with rhokinase (ROCK)-dependent phosphorylation of myosin phosphatase-targeting subunit (MYPT1)," Molecular Human Reproduction, vol. 18, no. 5, pp. 265-279, 2012.

[35] J. Paul, K. Maiti, M. Read et al., "Phasic Phosphorylation of Caldesmon and ERK 1/2 during contractions in Human Myometrium," PLoS ONE, vol. 6, no. 6, Article ID e21542, 2011.

[36] K. J. Livak and T. D. Schmittgen, "Analysis of relative gene expression data using real-time quantitative PCR and the $2^{-\Delta \Delta C_{T}}$ method," Methods, vol. 25, no. 4, pp. 402-408, 2001.

[37] A. A. Mosher, K. J. Rainey, S. S. Bolstad et al., "Development and validation of primary human myometrial cell culture models to study pregnancy and labour," BMC Pregnancy Childbirth, vol. 13, supplement 1, article S7, 2013.

[38] Y. Cordeaux, M. Tattersall, D. S. Charnock-Jones, and G. C. Smith, "Effects of medroxyprogesterone acetate on gene expression in myometrial explants from pregnant women," Endocrine Reviews, vol. 31, no. 5, pp. E437-E447, 2010.

[39] N. Chegini, C. Ma, X. M. Tang, and R. S. Williams, "Effects of $\mathrm{GnRH}$ analogues, 'add-back' steroid therapy, antiestrogen and antiprogestins on leiomyoma and myometrial smooth muscle cell growth and transforming growth factor- $\beta$ expression," Molecular Human Reproduction, vol. 8, no. 12, pp. 1071-1078, 2002.

[40] M. J. Taggart, P. Arthur, B. Zielnik, and B. F. Mitchell, "Molecular pathways regulating contractility in rat uterus through late gestation and parturition," American Journal of Obstetrics and Gynecology, vol. 207, no. 1, pp. 76e15-76e24, 2012. 
[41] G. A. Peters, L. Yi, Y. Skomorovska-Prokvolit et al., "Inflammatory stimuli increase progesterone receptor-a stability and transrepressive activity in myometrial cells," Endocrinology, vol. 158, no. 1, pp. 158-169, 2017.

[42] J. J. Li and M. D. Biggin, "Gene expression. Statistics requantitates the central dogma," Science, vol. 347 , no. 6226, pp. 10661067, 2015.

[43] M. Jovanovic, M. S. Rooney, P. Mertins et al., "Immunogenetics. Dynamic profiling of the protein life cycle in response to pathogens," Science, vol. 347, no. 6226, Article ID 1259038, 2015.

[44] T. Welsh, M. Johnson, L. Yi et al., "Estrogen receptor (ER) expression and function in the pregnant human myometrium: Estradiol via ER $\alpha$ activates ERK1/2 signaling in term myometrium," Journal of Endocrinology, vol. 212, no. 2, pp. 227-238, 2012.

[45] J. W. Paul, S. Hua, M. Ilicic et al., "Drug delivery to the human and mouse uterus using immunoliposomes targeted to the oxytocin receptor," American Journal of Obstetrics and Gynecology, vol. 216, no. 3, pp. 283.el-283.el4, 2017.

[46] M. Rezapour, T. Bäckström, B. Lindblom, and U. Ulmsten, "Sex steroid receptors and human parturition," Obstetrics and Gynecology, vol. 89, no. 6, pp. 918-924, 1997.

[47] D. Pieber, V. C. Allport, F. Hills, M. Johnson, and P. R. Bennett, "Interactions between progesterone receptor isoforms in myometrial cells in human labour," Molecular Human Reproduction, vol. 7, no. 9, pp. 875-879, 2001.

[48] J. R. G. Challis, S. G. Matthews, W. Gibb, and S. J. Lye, "Endocrine and paracrine regulation of birth at term and preterm," Endocrine Reviews, vol. 21, no. 5, pp. 514-550, 2000.

[49] E. R. Norwitz, J. N. Robinson, and J. R. G. Challis, “The control of labor," New England Journal of Medicine, vol. 341, no. 9, pp. 660-666, 1999.

[50] R. De Hertogh, K. Thomas, Y. Bietlot, I. Vanderheyden, and J. Ferin, "Plasma levels of unconjugated estrone, estradiol and estriol and of HCS throughout pregnancy in normal women," The Journal of Clinical Endocrinology \& Metabolism, vol. 40, no. 1, pp. 93-101, 1975.

[51] R. Smith, J. I. Smith, X. Shen et al., "Patterns of plasma corticotropin-releasing hormone, progesterone, estradiol, and estriol change and the onset of human labor," J Clin Endocrinol Metab, vol. 94, no. 6, pp. 2066-2074, 2009.

[52] B. S. Katzenellenbogen, "Mechanisms of action and cross-talk between estrogen receptor and progesterone receptor pathways.," Journal of the Society for Gynecologic Investigation, vol. 7, no. 1, pp. S33-S37, 2000.

[53] B. S. Katzenellenbogen, A. M. Nardulli, and L. D. Read, "Estrogen regulation of proliferation and hormonal modulation of estrogen and progesterone receptor biosynthesis and degradation in target cells," Progress in Clinical and Biological Research, vol. 322, pp. 201-211, 1990.

[54] J. A. Z. Loudon, S. R. Sooranna, P. R. Bennett, and M. R. Johnson, "Mechanical stretch of human uterine smooth muscle cells increases IL-8 mRNA expression and peptide synthesis," Molecular Human Reproduction, vol. 10, no. 12, pp. 895-899, 2004.

[55] S. R. Sooranna, Y. Lee, L. U. Kim, A. R. Mohan, P. R. Bennett, and M. R. Johnson, "Mechanical stretch activates type 2 cyclooxygenase via activator protein-1 transcription factor in human myometrial cells," Molecular Human Reproduction, vol. 10, no. 2, pp. 109-113, 2004.

[56] K. Lei, L. Chen, B. J. Cryar et al., "Uterine stretch and progesterone action," The Journal of Clinical Endocrinology \& Metabolism, vol. 96, no. 6, pp. E1013-E1024, 2011.
[57] C.-W. Ou, Z.-Q. Chen, S. Qi, and S. J. Lye, "Increased expression of the rat myometrial oxytocin receptor messenger ribonucleic acid during labor requires both mechanical and hormonal signals," Biology of Reproduction, vol. 59, no. 5, pp. 1055-1061, 1998.

[58] C.-W. Ou, A. Orsino, and S. J. Lye, "Expression of connexin-43 and connexin-26 in the rat myometrium during pregnancy and labor is differentially regulated by mechanical and hormonal signals," Endocrinology, vol. 138, no. 12, pp. 5398-5407, 1997.

[59] L. J. Parry and R. A. Bathgate, "The role of oxytocin and regulation of uterine oxytocin receptors in pregnant marsupials," Experimental Physiology, vol. 85, pp. 91s-99s, 2000.

[60] W. X. Wu, X. H. Ma, T. Yoshizato, N. Shinozuka, and P. W. Nathanielsz, "Differential expression of myometrial oxytocin receptor and prostaglandin $\mathrm{H}$ synthase 2 , but not estrogen receptor $\alpha$ and heat shock protein 90 messenger ribonucleic acid in the gravid horn and nongravid horn in sheep during betamethasone-induced labor," Endocrinology, vol. 140, no. 12, pp. 5712-5718, 1999.

[61] Y.-L. Dong, L. Fang, S. Kondapaka, P. R. Gangula, S. J. Wimalawansa, and C. Yallampalli, "Involvement of calcitonin generelated peptide in the modulation of human myometrial contractility during pregnancy," Journal of Clinical Investigation, vol. 104, no. 5, pp. 559-565, 1999.

[62] G. N. Europe-Finner, S. Phaneuf, A. M. Tolkovsky, S. P. Watson, and A. Lopez Bernal, "Down-regulation of G alpha s in human myometrium in term and preterm labor: a mechanism for parturition," Journal of Clinical Endocrinology \& Metabolism, vol. 79, no. 6, pp. 1835-1839, 1994.

[63] G. N. Europe-Finner, S. Phaneuf, S. P. Watson, and A. L. Bernal, "Identification and expression of G-proteins in human myometrium: up-regulation of $\mathrm{G} \alpha \mathrm{s}$ in pregnancy," Endocrinology, vol. 132, no. 6, pp. 2484-2490, 1993.

[64] A. Lopez Bernal, J. Rivera, G. N. Europe-Finner, S. Phaneuf, and G. Asboth, "Parturition: activation of stimulatory pathways or loss of uterine quiescence?" Advances in Experimental Medicine and Biology, no. 395, pp. 435-451, 1995.

[65] J. Zuo, Z. M. Lei, and C. V. Rao, "Human myometrial chorionic gonadotropin/luteinizing hormone receptors in preterm and term deliveries," Journal of Clinical Endocrinology and Metabolism, vol. 79, no. 3, pp. 907-911, 1994.

[66] G. Madsen, T. Zakar, C. Y. Ku, B. M. Sanborn, R. Smith, and S. Mesiano, "Prostaglandins differentially modulate progesterone receptor-A and -B expression in human myometrial cells: evidence for prostaglandin-induced functional progesterone withdrawal," Journal of Clinical Endocrinology and Metabolism, vol. 89, no. 2, pp. 1010-1013, 2004.

[67] W. Elger and S. G. Hasan, "Studies on the mechanism of action of antifertile PG in animal models," Acta Physiol Hung, vol. 65, no. 4, pp. 415-32, 1985.

[68] W. Elger, S. H. Hasan, and E. Friedreich, "Uterine' and 'luteal' effects of prostaglandins (PG) in rats and guinea pigs as potential abortifacient mechanisms," Acta Endocrinologica, Supplement, vol. 173, p. 46, 1973.

[69] Y. Sugimoto, A. Yamasaki, E. Segi et al., "Failure of parturition in mice lacking the prostaglandin F receptor," Science, vol. 277, no. 5326, pp. 681-683, 1997.

[70] M. Embrey, "Pge compounds for induction of labour and abortion," Annals of the New York Academy of Sciences, vol. 180, no. 1, pp. 518-523, 1971.

[71] M. P. Embrey, "Prostaglandins in human reproduction," British Medical Journal (Clinical Research ed.), vol. 283, no. 6306, pp. 1563-1566, 1981. 
[72] J. K. Jain and D. R. Mishell Jr., "A comparison of intravaginal misoprostol with prostaglandin E2 for termination of secondtrimester pregnancy," New England Journal of Medicine, vol. 331, no. 5, pp. 290-293, 1994.

[73] J. Robins and L. I. Mann, "Midtrimester pregnancy termination by intramuscular injection of a 15 methyl analogue of prostaglandin F2 alpha," American Journal of Obstetrics and Gynecology, vol. 123, no. 6, pp. 625-631, 1975.

[74] R. Romero, J. Espinoza, L. F. Gonçalves, J. P. Kusanovic, L. Friel, and S. Hassan, "The role of inflammation and infection in preterm birth," Seminars in Reproductive Medicine, vol. 25, no. 1, pp. 21-39, 2007.

[75] P. Mittal, R. Romero, A. L. Tarca et al., "Characterization of the myometrial transcriptome and biological pathways of spontaneous human labor at term," Journal of Perinatal Medicine, vol. 38, no. 6, pp. 617-643, 2010.

[76] J. E. Norman, S. Bollapragada, M. Yuan, and S. M. Nelson, "Inflammatory pathways in the mechanism of parturition," $B M C$ Pregnancy and Childbirth, vol. 7, supplement 1, article S7, 2007.

[77] I. Osman, A. Young, M. A. Ledingham et al., "Leukocyte density and pro-inflammatory cytokine expression in human fetal membranes, decidua, cervix and myometrium before and during labour at term," Molecular Human Reproduction, vol. 9, no. 1, pp. 41-45, 2003.

[78] A. J. Thomson, J. F. Telfer, A. Young et al., "Leukocytes infiltrate the myometrium during human parturition: further evidence that labour is an inflammatory process," Human Reproduction, vol. 14, no. 1, pp. 229-236, 1999.

[79] A. Young, A. J. Thomson, M. Ledingham, F. Jordan, I. A. Greer, and J. E. Norman, "Immunolocalization of proinflammatory cytokines in myometrium, cervix, and fetal membranes during human parturition at term," Biology of Reproduction, vol. 66, no. 2, pp. 445-449, 2002.

[80] T. M. Lindström and P. R. Bennett, "The role of nuclear factor kappa B in human labour," Reproduction, vol. 130, no. 5, pp. 569581, 2005.

[81] D. B. Hardy, B. A. Janowski, D. R. Corey, and C. R. Mendelson, "Progesterone receptor plays a major antiinflammatory role in human myometrial cells by antagonism of nuclear factor- $\kappa \mathrm{B}$ activation of cyclooxygenase 2 expression," Molecular Endocrinology, vol. 20, no. 11, pp. 2724-2733, 2006.

[82] J. C. Condon, P. Jeyasuria, J. M. Faust, J. W. Wilson, and C. R. Mendelson, "A decline in the levels of progesterone receptor coactivators in the pregnant uterus at term may antagonize progesterone receptor function and contribute to the initiation of parturition," Proceedings of the National Academy of Sciences of the United States of America, vol. 100, no. 16, pp. 9518-9523, 2003.

[83] M. A. Wilson, A. R. Ricci, B. J. Deroo, and T. K. Archer, “The histone deacetylase inhibitor trichostatin A blocks progesterone receptor-mediated transactivation of the mouse mammary tumor virus promoter in vivo," Journal of Biological Chemistry, vol. 277, no. 17, pp. 15171-15181, 2002.

[84] M. van Zijl, B. Koullali, B. W. Mol, E. Pajkrt, and M. Oudijk, "Prevention of preterm delivery: current challenges and future prospects," International Journal of Women's Health, vol. 8, pp. 633-645, 2016. 


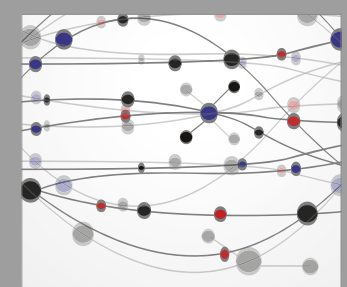

The Scientific World Journal
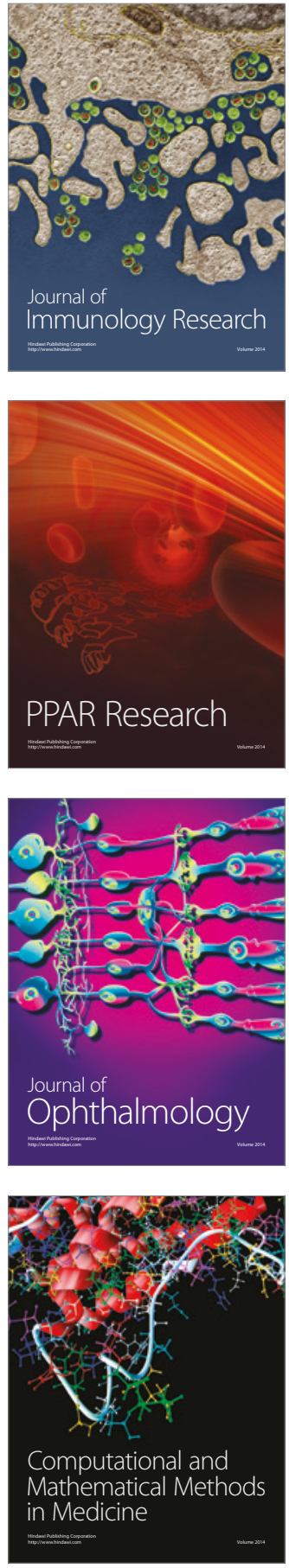

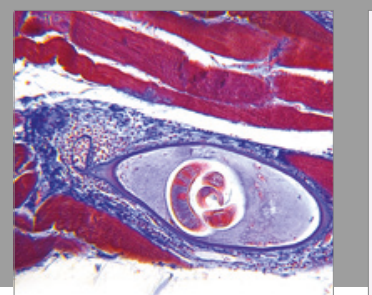

Gastroenterology Research and Practice
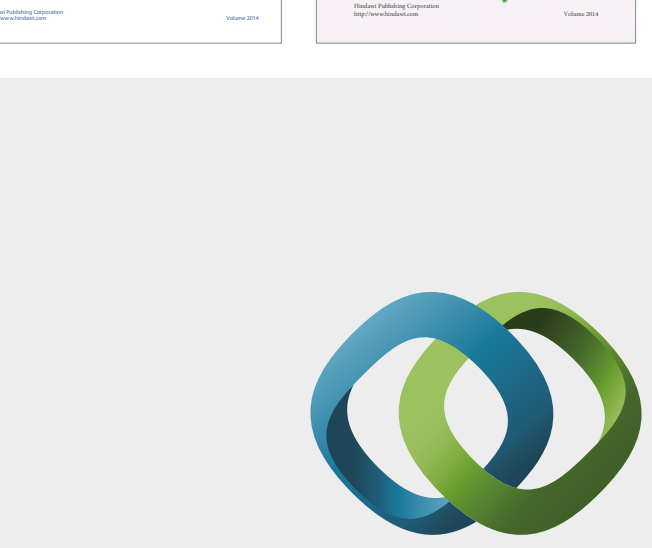

\section{Hindawi}

Submit your manuscripts at

https://www.hindawi.com
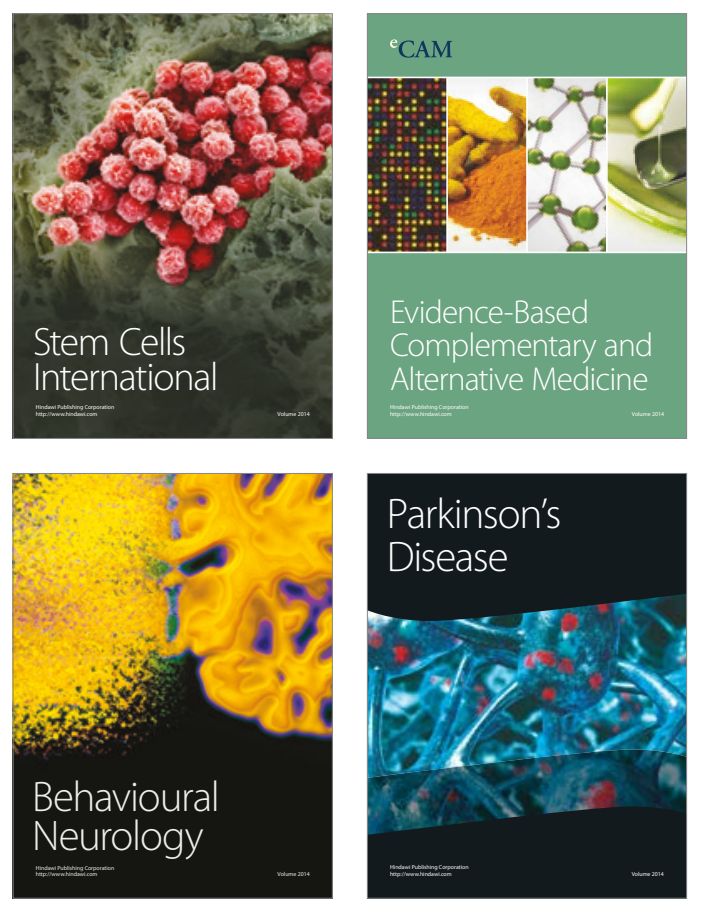
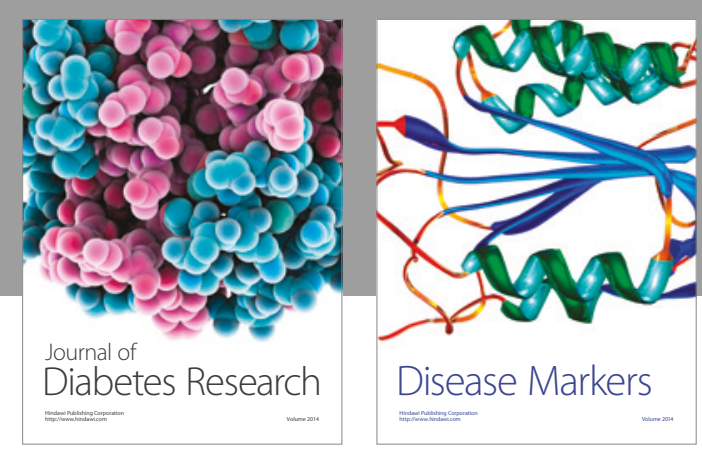

Disease Markers
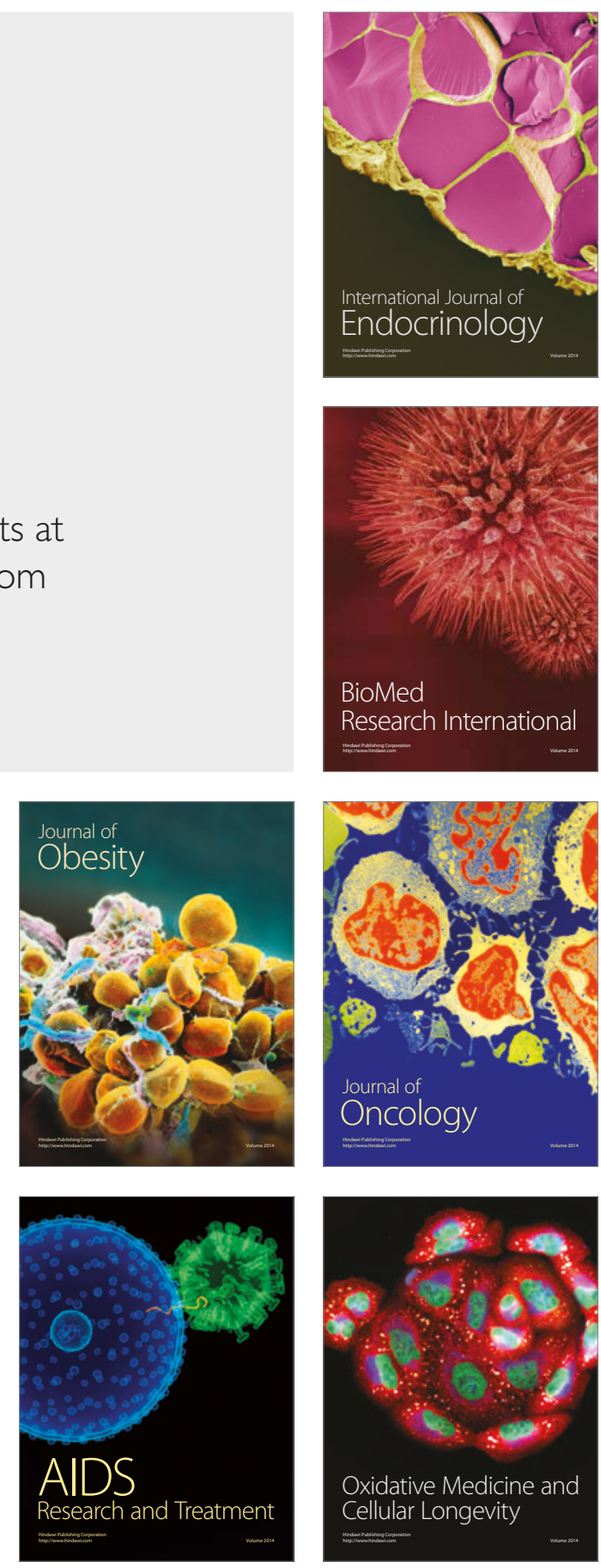